Elsevier required licence: (C) <2017>. This manuscript version is made available under the CC-BY-NC-ND 4.0 license http://creativecommons.org/licenses/bync-nd/4.0/ 


\title{
The value of bank capital buffers in maintaining financial system resilience
}

\author{
Christina Bui, Harald Scheule ${ }^{1}$ and Eliza $\mathrm{Wu}^{2,3}$ \\ This version: October 13, 2017
}

\begin{abstract}
There is a current controversy concerning the appropriate size of banks' capital requirements, and the trade-off between the costs and benefits of implementing higher capital requirements. We quantify the size of capital buffers required to reduce system-wide losses using confidential regulatory data for Australian banks from 2002 to 2014 and annual public accounts from 1978 to 2014. We find that a moderate increase in bank capital buffers is sufficient to maintain financial system resilience, even after taking economic downturns into consideration. Furthermore, while banks benefit from paying a lower cost of debt when they have a higher capital buffer, lending volumes are lower indicating that credit supply may be hampered if bank capital levels are too high within a financial system.
\end{abstract}

JEL Classification: G21, G28

Keywords: Capital Buffer, Loan Loss Provisions, Systemic Risk, Financial Resilience.

\footnotetext{
${ }^{1}$ Finance Discipline Group, UTS Business School, University of Technology Sydney, PO Box 123, Broadway NSW 2007, Australia, Christina.Bui@uts.edu.au, Harald.Scheule@uts.edu.au.

2 The University of Sydney Business School, The University of Sydney, NSW, 2006, Eliza.Wu@sydney.edu.au

3 The support by the Center for International Finance and Regulation (CIFR, project number F002) is gratefully acknowledged. CIFR was funded by the Commonwealth and NSW Governments and supported by other consortium members (see www.cifr.edu.au). We thank the Australian Prudential Regulation Authority and in particular Charles Littrell (Executive General Manager, Policy, Supervisory Support Division), David Connolly (Manager, Banking Statistics - Policy, Statistics and International Division) and Meghann Garry (Senior Statistics Analyst - Supervisory Support Division) for the provision of data as well as helpful feedback. We thank Michael Hawari and Mai Luong for valuable research assistance. Wu would also like to acknowledge the support from the Australian Research Council for DP170101413. We are grateful to Charles Calomiris, Talis Putnins, Lorenzo Casavecchia, Marco Navone, Ben Marshall, Shams Pathan, Amelia Pais Rodriguez, Alden Toevs, David Tripe, Bill Wilson, and two anonymous CIFR referees for helpful comments. All errors remain our own. We would also like to thank participants in seminars at the University of Technology Sydney and Massey University as well as the 7th Financial Markets and Corporate Governance Conference, the Paul Wooley Centre for Financial Market Dysfunctionality Workshop, the UTS PhD Symposium, the CIFR Banking Research Symposium and the IGF/ADB Financial Cycles, Systemic Risk, Interconnectedness, and Policy Options for Resilience Conference 2016. All errors remain our own.
} 


\section{Introduction}

There is a current debate concerning the appropriate size of capital requirements for banks to mitigate system-wide losses, and the economic trade-off associated with raising more capital. Admati and Hellwig (2014) propose that financial institutions should raise their capital levels by $12 \%$ from current levels ${ }^{4}$, arguing that banks are unconstrained in their capital funding. The Bank of England (2016) has proposed to increase minimum capital levels via a systemic importance buffer of up to $2.5 \%{ }^{5}$. These numbers are in addition to the capital maintenance buffer and countercyclical capital buffer under Basel III. However, as equity is costly the trade-off between the costs and benefits of raising capital is controversial. Higher capital is often associated with higher funding $\operatorname{costs}^{6}$ and lower lending volumes, which in turn leads to lower economic activity.

In this paper, we analyse the dynamics of loan loss rates and the interactions of such dynamics on banks' capital buffers and system resilience using a sample of Australian banks. In addition, we also examine the implications of raising capital for banks' funding costs and profitability. We define capital buffers as the difference between the observed capital of banks and the minimum capital requirements.

Australia offers a unique setting to study the link between systemic risk and capital buffers as it overcomes the data constraint faced in many other economies for which bank data has not been collected through periods of significant financial distress for a wide cross-section of banks. The finding of variations in systemic risk for different time periods can hence, be extrapolated and read with interest for many other open economies with limited downturn data, which in total comprise a significant proportion of global banking assets. In this study, systemic risk is defined as the common shock to loan loss provisions in excess of anticipated loan loss provisions and existing capital levels. The detailed prudential data collected by the Australian Prudential Regulation Authority (APRA) on Australian Deposit-taking Institutions is paramount to our objective to better understand the impact of bank capital on system-wide losses.

Our study contributes to the existing banking literature (in particular within the AsiaPacific region) on banks' credit losses and their interactions with financial system resilience

\footnotetext{
${ }^{4}$ Admati and Hellwig (2014) propose increasing total bank capital from the current $13 \%$ to $25 \%$.

${ }^{5}$ The Bank of England's views have been acknowledged internationally in the context capital buffers. The Brexit referendum has had so far no consequence on bank capital regulations. It is unclear whether Britain will change these views in the future.

${ }^{6}$ See Cummings and Wright (2016).
} 
and capital buffers in several ways. Firstly, we provide empirical evidence on the role of the inclusion of economic downturns in measuring systemic risk. To the best of our knowledge, this study is the first that analyses the systemic risk of the Australian banking system whilst accounting for business cycles. We highlight the importance of using an economic downturn period in the analysis of bank loan losses. The evidence further suggests a possibility that banks that have adopted the internal ratings based (IRB) approach using recent data do not fully account for the likelihood of banking crises in their internal models and consequently may be undercapitalized during financial crises under the Basel capital adequacy framework.

Secondly, we quantify the relationship between banks' capital buffers and the size of the financial safety net. Most extant studies examine the direction of this relationship (see for instance, Thakor, 2014), yet few have looked at this aspect in measurable terms. Using our simulation study, we measure the size of financial safety nets based on the capital buffers and show that there is a non-linear impact on system resilience for larger capital buffers. The size of the Australian financial system protection schemes is measured by computing the absolute losses (in excess of capital buffers) in the system. These losses are not explained by loan loss provisioning models and hence, serve as a reflection of unexpected risk. Specifically, we examine two unconditional loss measures for systemic risk - Value-at-Risk (VaR) and Conditional Value-at-Risk (henceforth, Expected Shortfall). Our findings support the moderate capital buffer increase of about $2 \%$ on top of current levels as proposed by the Bank of England.

Thirdly, we are able to affirm that higher loss rates lead to higher funding costs faced by banks, while the funding costs decrease as banks' capital buffers increase. Specifically, an increase in banks' capital buffers is associated with a reduction in the cost of debt financing. Furthermore, we also document a slight decrease in loan growth following an increase in capital levels. The results contribute to the debate regarding the trade-off between the benefit of lowering banks' funding costs and the reduction in credit supply within the banking sector.

The paper proceeds as follows. Section 2 summarises the relevant literature that motivate the current study. Section 3 outlines the data. Section 4 describes the research design, and presents the main empirical results and robustness checks. Section 5 discusses the controversial impacts of higher capital requirements. Section 6 concludes the paper. 


\section{Related literature}

\subsection{Financial system resilience}

Our study relates to the growing literature on financial resilience. System resilience refers to the ability of the financial system to withstand or recover from losses, should they incur. The impact of system-wide losses on the real economy can be measured by examining the interconnections between the financial markets and various industry sectors. Banks are documented as the industry group that has most systemic risk in Australia (Dungey et al., 2014). Other international studies also propose different methods for systemic risk modeling. For instance, Souza (2016) models the Brazilian banking system as a network of banks mutually exposed, in which the medium-sized banks can impose a significant contribution to systemic risk.

As shown in prior studies, systemic risk levels can also be used to provide early warning signals for ensuing financial crises and is closely related to future economic downturns (Allen et al., 2012; Zhang et al., 2015; Acharya et al., 2017).

The literature on Asian countries has mainly focused on market-based approaches to measuring systemic risk. Using equity price information, Fong et al. (2011) and Wong et al. (2011) assess the systemic risk, based on the Conditional Value-at-Risk, of the Hong Kong banking sector using loan loss provisioning and Merton default probabilities, respectively. To understand the build-up of systemic losses within a financial system, recent papers also measure the interconnectedness between banks and different sectors in the Australian economy and international markets (Dungey et al., 2016; Anufriev and Panchenko, 2015). More recently, Roesch and Scheule (2016) develop an econometric model to analyse systemic risk in relation to bank lending for Asian economies using bank portfolio loss rates.

The related literature on bank financial resilience (Brownlees and Engle, 2017; Adrian and Brunnermeier, 2016; and Acharya et al., 2017) relies on traded share prices and credit default swap spreads that are available only for a small number of larger sized banks and this severely limits the usefulness of these existing systemic risk measures. Brownlees and Engle (2017) propose an index (SRISK) to capture the systemic risk contribution of a financial firm and the aggregate financial system using public information on market and firm returns. This index is measured by the expected capital shortage that a firm would experience in times of a substantial market decline, which is related to the conditional equity loss (i.e. Marginal Expected Shortfall). 
Similarly, Acharya et al. (2017) look at an individual bank's contribution to systemic risk by measuring its systemic expected shortfall (SES) using bank assets, and the book and market value of equity. This SES measure is interpreted as the expected amount that a bank is undercapitalized in the event that the whole system is undercapitalized.

On the other hand, Adrian and Brunnermeier (2016) suggest an alternative systemic risk measure, which is the conditional Value at Risk $(\mathrm{CoVaR})$ of a financial sector conditioning on whether a bank has had a VaR exceeding loss. The main distinction between the systemic risk measures of Adrian and Brunnermeier (2016) and Acharya et al. (2017) is that the CoVaR measure looks at the system's stress given that an individual firm is experiencing stress, while the latter analyses a financial firm's stress conditional on a systemic stress. Their empirical analysis also uses equity prices for US publicly traded financial institutions.

Sedunov (2016) compares different measures of institution-level systemic risk exposure and concludes that the CoVaR methodology gives the best forecasts of institutions' within-crisis performance over several crisis periods. He modifies Adrian and Brunnermeier's (2016) CoVaR to allow for more reliable forecasts of future systemic risk exposures.

Our paper looks at the unconditional losses to the Australian financial system at the aggregate level. The approach taken delineates from existing work, as we do not analyse systemic risk in the sense of a systemic loss conditioning on individual banks' failures (see Adrian and Brunnermeier, 2016) or the reverse causality of the impact of the financial system losses on individual financial institutions (see e.g., Acharya et al., 2017). Another key contribution is that the framework is completely independent from the efficiency of financial markets and the criticism made by Borio and Drehmann (2009) and Cerutti et al. (2012). They argue that the financial markets may be exposed to systematic under and/or over pricing, which results in a higher degree of systemic risk than under real-world measures. As such, the use of stock market data might pose challenges. Our framework provides a significant methodological contribution in that it uses non-market-based information and can be used to reliably assess financial institutions of all sizes.

\subsection{Capital buffer and capital regulation}

From a macro-prudential perspective, raising the level and quality of capital in the system is proposed as a way to ensure effective loss absorbing capacity. To mitigate the buildup of systemic loss, the Basel Committee has focused on its two main dimensions, 
procyclicality and interconnections between banks (Caruana, 2012). The countercyclical buffer aims to mitigate the former dimension while the requirement of higher loss absorbing capacity aims to resolve the latter. From January 2013, the new Basel III framework introduced a countercyclical buffer of between 0 and $2.5 \%$ of risk weighted assets (RWA), in addition to a conservation buffer for common equity Tier 1 capital of $2.5 \%$, to protect the banking system during economic downturns (Basel Committee on Banking Supervision, 2011 and 2014).

Using a calibration technique, Miles et al. (2013) provide insights into the long-run costs and benefits of financing more of the assets with equity. The desirable amount of capital is estimated to be higher than the target level under Basel III. Regarding the procyclicality concern, Ayuso et al. (2004) find a negative relationship between the Spanish business cycle and capital buffers held by Spanish commercial and savings banks from 1986 to 2000. Their results suggest that an increase by one percentage point in GDP growth might reduce capital buffers by $17 \%$. Other papers also confirm the benefits of holding higher capital. Heid (2007) looks into why the Basel capital buffers increase during the crises and finds that the capital buffer that banks hold on top of the required minimum capital plays a crucial role in mitigating the impact of the volatility of capital requirements due to risk changes. Thakor (2014) shows that higher capital is associated with higher lending, higher liquidity creation and banks' value as well as their survival likelihood during the crises.

By contrast, Cajueiro et al. (2011) use a sample of Brazillian banks for the period 20002010 and find that the surplus capital is negatively related with loan growth. They also argue that in the economic turmoil, banks may reduce their loans as a way to increase their capitalization. Kosak et al. (2015) reconcile the controversial debate by showing that the interactions between banks' capital and lending depend on the state of the economy. In an international bank sample, they find that during the crisis larger banks lend more if the Tier 1 capital ratio of competing banks was low, but this pattern reverses in normal times. Further, Gambacorta and Shin (2016) look at the effect of bank capital on funding costs and lending growth using a sample of major international banks over the period 1994-2007. Cummings and Wright (2016) show theoretically that higher capital leads to lower cost of equity and debt and may lead to higher total funding costs. Higher total funding costs may result as the capital ratio increases and cost of equity is greater than the cost of debt.

Our paper extends the current empirical literature on bank capital as it uniquely assesses the consequences of higher capital buffers on financial system resilience, cost of debt and credit supply. 


\subsection{Prediction of banks' credit losses and their interactions}

Our study is also related to the extant literature focused on banks' loan loss provisioning behaviour. This strand of the banking literature finds that bank characteristics and business cycles are important determinants of loss rates. Dermine and De Carvalho (2008) estimate dynamic provisions for non-performing loans of Portuguese banks over time. Other prior studies analyse the determinants of loan loss provisions using banks' financial ratios and economic factors both in the US and abroad. Banks are found to increase capital levels when loan loss provisions decrease (Ahmed et al., 1999), postpone provisioning until negative economic conditions have set in (Laeven and Majnoni, 2003; Bikker and Metzemakers, 2005) and use loan loss provisions more extensively in crisis times (El Sood, 2012). Furthermore, in a global sample based on 16 major countries (including US, European countries and Japan) over 1997-2007, Foos et al. (2010) find that past loan growth has a significant and positive impact on banks' loan loss provisions. In line with this finding, Fahlenbrach et al. (2017) show that banks with loan growth rates in the top quartile tend to increase their loan loss reserves following periods of high loan growth.

With regard to Australia, Hess et al. (2009) study the determinants of credit losses at 32 Australasian banks over 1980-2005 and conclude that loan growth is strongly related to credit losses in the next two to four years, with evidence of income smoothing patterns. Rodgers (2015) also studies credit losses using annual reports of Australian banks from 1980. The results indicate that business lending was the main driver of the credit losses experienced during the recession in the 1990s and also recently in the Global Financial Crisis (GFC). More recently, Cummings and Durrani (2016) examine the effects of the Basel capital requirements on the loan-loss provisioning practices of 22 Australian banks. The authors show that internalratings based (IRB) banks use surplus regulatory capital to support their specific and general provisions after the adoption of the IRB framework.

Overall, previous studies have focused exclusively on the prediction of loss rates for short horizons, usually over a one-year term. Our study provides a comprehensive assessment for multiple year loss rates. The analysis of multi-year loss rates is important as these reflect the banks' exposure during distressed times when banks are unable to recapitalise.

\section{Data}




\subsection{Data sources}

We use financial data for Australian Authorised Deposit-taking Institutions (ADIs) from 2002 to 2014, collected and provided by the Australian Prudential Regulation Authority (APRA). All balance sheet and profit and loss items are analysed at the quarterly frequency and relate to the end of each quarter.

We apply two data filters. First, we exclude banks with fewer than 15 quarters of observations, or missing values for the entire sample period. Second, we exclude financial companies classified as building societies, credit unions and foreign bank branches. The first filter allows us to have sufficient and reliable quarterly observations for our simulation study. Following Cummings and Durrani (2016), the second filter restricts our analysis to domestic banks. In addition, we drop outliers and extreme values by winsorizing financial ratios (except size) and regulatory capital variables at the $5^{\text {th }}$ and $95^{\text {th }}$ percentiles. ${ }^{7}$ The final sample is a panel data set that consists of 25 banks. These filter rules have a minor impact on the economic significance of our findings. As of the last quarter of the sample (2014:Q4), the Australian banking system has $\$ 3.2$ trillion $^{8}$ in assets, of which we analyse $90 \%$ of the total assets.

There are several merits in using the APRA data. Firstly, this regulatory bank data allows us to identify the risk-weighted assets and capital requirements of banks. Secondly, the data is available for all licensed public and private banks. Thirdly, we are able to draw conclusions on the limitations of regulatory data to assess systemic risk. Fourthly, our funding cost analysis is timely as we are able to control for the repricing of bank liabilities.

Despite its advantages, the data is only available for the period 2002-2014. This limits our ability to measure the financial system resilience in relation to economic downturns. To address this issue, we have hand collected an extended dataset using banks' public annual reports and reconciled with the commercial (but lower coverage) Ausaspect database. We have a sample of 19 banks from 1978 to $2014^{9}$. Note that six (generally smaller) banks have not published their annual accounts. This data includes the economic downturn in Australia in 1991, which is generally seen as a major banking system crisis that affected both Australia and New Zealand simultaneously (see e.g., Hess et al., 2009).

\footnotetext{
${ }^{7}$ We do not winsorize based on bank size (i.e., total assets) as this would compromise the representativeness of our sample banks in the Australian banking system.

${ }^{8}$ The value of total Australian banking assets is obtained from APRA data. It is calculated as the sum of all banks' assets as of December 2014.

${ }^{9}$ Our annual data starts from 1978 to ensure two aspects: (1) having sufficient observations for estimation, and (2) capturing economic downturn in 1991.
} 
The APRA data relates to the domestic books of licensed deposit-taking institutions while the annual data relates to the consolidated accounts, including foreign branches and subsidiaries. Despite this difference, we find consistent financial ratios for the two data sources indicating that they are comparable. For a consistent comparison with the annual sample, we annualise all our quarterly financial ratios (from APRA). Figure 1 reveals the patterns in total assets and loss rates over the sample period for quarterly and annual data. The shaded grey area depicts the periods when the GDP growth rate is negative.

\section{(insert Figure 1 about here)}

As seen in the first chart of Figure 1, the loss rates increased to about $0.5 \%$ per year in the GFC. The total assets follow an upward trend, which is consistent with our priors. As of 2014 , the sample banks account for total assets of $\$ 2.9$ trillion.

Since the annual report data collects banks' financials on a consolidated holding level, the total assets from the second chart are slightly higher than the reported values in the first one for the commercial banks. Overall, the same patterns in banks' loss rates and assets are shown in both figures. Interestingly, the increase of loss rates during the recent GFC is not as dramatic as the one observed during the Australian banking crisis in 1991. The average yearly loss rate increased to approximately $0.7 \%$ in 1992 (following the economic downturn in the prior year). This fact reinforces the importance of our analysis in investigating the banks' loss rates and unconditional losses using data, which covers the major economic downturn in 1991.

\subsection{Capital variables for simulations}

The APRA enforces capital adequacy of all Australian banks. In 2013, APRA implemented Basel III and increased the requirements for both the quality and quantity of regulatory capital. As a result, the composition of Tier 1 and Tier 2 capital has also changed. Tier 1 capital must be at least $6 \%$ (of RWA), of which $4.5 \%$ must be from common equity. The combination of Tier 1 and Tier 2 capital must be at least $8 \%$ of the risk-weighted assets. Regarding the capital buffer levels, APRA requires all locally incorporated ADIs to hold a capital buffer consisting of three components: a capital conservation buffer $(2.5 \%$ of risk- 
weighted assets), a countercyclical capital buffer (currently set at $0 \%$ ) and an additional buffer (1\% of risk-weighted assets) for domestically systemically important bank (D-SIB).

For our study, we require detailed information on the banks' observed and regulatory capital in the APRA data, including Tier 1 and Tier 2 capital and total risk-weighted assets. Tier 1 capital consists of high-quality capital with which a bank can cover losses without bankruptcy, such as core capital and retained earnings, while the sum of book value of Tier 1 and Tier 2 capital represents the observed capital (TIER_CAP) that banks hold. We define the regulatory capital $\left(R E G_{-} C A P\right)$ as the minimum level of capital that banks are required to hold, which is $8 \%$ of a bank's total risk-weighted assets. In addition, a countercyclical and a capital conservation buffer are required under Basel III, which may cover credit losses in severe economic downturns. We assume that the whole capital buffer is available for loss absorption should loan losses exceed expectations. The consequence of this assumption is that the countercyclical capital buffer and the capital conservation buffer can be used to reduce the losses. Therefore, a bank's capital buffer $\left(C A P \_B U F F E R\right)$ is calculated as the difference between the book value of observed capital and the regulatory capital threshold excluding the capital conservation buffer and the countercyclical capital buffer.

\section{Dynamics of loss rates, capital buffer and system resilience}

\subsection{Research design}

This study is divided into two parts, which (i) analyse bank portfolio level loss rates and (ii) relate bank credit losses and capital buffers to system losses. Our approach is summarised in Figure 2.

\section{(insert Figure 2 about here)}

We analyse two datasets that mainly differ in their coverage to fully utilise their advantages and limit shortcomings. The quarterly APRA data includes detailed level information on regulatory capital but is limited in the time series as it starts in 2002. The observation subjects are commercial banks. The annual data starts in 1978 and covers the severe economic downturn of 1991 but provides less information on regulatory capital, as this disclosure is not mandated. Observation subjects are bank holding companies. 


\section{Stage 1: Model estimation of loss rates}

In the first stage, we model the average loss rate using (a) APRA data and (b) annual data. We apply various reference periods for the dependent variable: one year, two years and three years for both (a) and (b).

In reference to Roesch and Scheule (2016), we employ a panel mixed model to predict future credit losses using contemporaneous bank-level and macroeconomic variables. This allows the residuals to be decomposed into a systematic risk exposure $\left(\varepsilon_{t+1, \tau}\right)$ and a bankidiosyncratic risk exposure $\left(\varepsilon_{i, t+1, \tau}\right)$. The estimation model is as follows ${ }^{10}$ :

$$
L R_{i, t+1, \tau}=\alpha_{i}+\beta X_{i, t}+\gamma \varepsilon_{t+1, \tau}+\delta \varepsilon_{i, t+1, \tau}
$$

The dependent variable for our regression is the average loss rate of bank i over a window of one-year, two-years and three-years ahead (where $\tau$ is 1, 2 and 3 years, respectively) from $t+1^{11}$. We define loss rates $(L R)$ as the flow measure of provisions for credit impairments scaled by total assets. ${ }^{12}$ The loss rates include losses in relation to credit portfolios, other investments and contingent guarantee contracts (such as standby letters of credit). To examine the predictions of loss rates at different time intervals, our annualised loss rates are leading by one year, two years and three years. The bank-level intercept $\left(\alpha_{i}\right)$ controls for unobservable heterogeneity across the banks. The parameters $\gamma$ and $\delta$ are the standard deviations of the standard normally distributed random variables, $\varepsilon_{t+1, \tau}$ and $\varepsilon_{i, t+1, \tau}$. Roesch and Scheule (2016) show that the mixture over standard normal random variables reflects tail risk. A set of explanatory variables is represented by the vector $X_{i, t}$ including current bank-level characteristics and macro-economic factors.

\footnotetext{
${ }^{10}$ We use the mixed models for the main results and a standard Ordinary Least Square (OLS) model for robustness. We have also confirmed that the linear prediction in the mixed model is comparable with the one resulting from the OLS model.

11 For example, when $t+1=2002: \mathrm{Q} 1$, the average loss rate over one, two and three years will be calculated for the periods 2002:Q2-2003:Q1 $(\tau=1)$, 2002:Q2-2004:Q1 $(\tau=2)$ and 2002:Q2-2005:Q1 $(\tau=3)$, respectively.

${ }^{12}$ Note that this variable is referred as 'Charge for bad and doubtful debts (data sheet ARF_330_0_L). A stock measure does not accurately reflect the change in loan loss provision as it could be declining in the current period due to some asset write-offs in earlier years even when new bad loans are incurred (compare Hess et al., 2008 and 2009). Further, the use of a stock measure may dilute our econometric results as it aggregates over provisions generated over multiple periods. We address this issue by using the flow measure as opposed to the stock variable of loan loss provisions. Further, we focus on the bank loss rates rather than the net income or trading income, as loss rates are a cleaner measure of the credit risk exposure.
} 
The first set of determinants includes bank-specific financial performance ratios (such as the liquidity ratio, loan growth, housing loan ratio, deposit, profitability, and size). The relation between banks' liquidity $(L I Q)$ and credit losses is expected to be negative, as banks with larger holdings of liquid assets would face lower credit losses from holding fewer loans. Following Foos et al. (2010), we use the two-year lagged value of loan growth (LOAN_GR) as opposed to current loan growth to account for the possibility that banks may not realise the losses relating to their loan portfolio until after some time ${ }^{13}$. We expect lagged loan growth to be positively related to loss rates. This is because banks tend to relax underwriting standards to expand credit supply, which would lead to greater credit risk exposure ${ }^{14}$. We also include the housing loan ratio (HLOAN) due to the concentration of Australian banks' in this category. It is anticipated that the housing loans would be negatively associated with future loss rates, as they are real estate-backed and generally imply lower loss rates. We have no prior expectations of the coefficients on deposit funding $(D E P)$, size $(S I Z E)$ and profitability (PROFIT). For example, large banks could either engage in riskier loans, which leads to a positive relation between bank size and loan losses, or they could be subject to greater market scrutiny and prudential monitoring that trigger lower future loss rates.

Regarding regulatory changes, the introduction of the International Financial Reporting Standards (IFRS) may have had an impact on loan loss rates. The accounting standards that were first adopted from January 2005 may have led banks to write back their losses, resulting in the decline in loss rates in the following periods. We control for the impact of the IFRS introduction by including a dummy variable that takes a value of one for the periods 2004:Q4 and 2005:Q1 for the APRA data and zero otherwise ${ }^{15}$.

Lastly, to capture the effect of the business cycle on banks' credit losses we include GDP growth $\left(G D P_{-} G R\right)$ and the change in unemployment rate (UNEMP_GR). We expect to observe a negative relationship between GDP growth and loss rates, but a positive relationship

\footnotetext{
${ }^{13}$ For robustness, we also use current loan growth, and other lag orders in the estimation model. The results remain qualitatively the same.

${ }^{14}$ It is also consistent with the evidence for the Japanese commercial banks (see Vithessonthi (2016) who finds that the bank loan supply increases the level of non-performing loans).

${ }^{15}$ Similarly, the IFRS binary variable for the annual sample is set to be one for the years 2004 and 2005 . We do not observe major changes in the loss rates following the introduction of the accounting standard IFRS 9 (such as increased loss rates in future years due to loan loss provisioning that relate to the lifetime of financial instruments rather than the current one-year reference period) in 2014 and the mergers between Commonwealth Bank of Australia and Bankwest, and between Westpac Banking Corporation and St George. Hence, we do not include indicator variables for those events.
} 
between the unemployment rate and loss rates. We summarise the definitions and data sources for all variables used in this study in Table 1.

(insert Table 1 about here)

\section{Stage 2: Simulation of system losses}

In the second stage, we apply the three-year loss rate models in a simulation study to assess the impact of three-year cumulative bank losses. Monte Carlo simulation is a popular technique to analyse future outcomes based on credible assumptions. For example, Miles et al. (2013) analyse the optimal capital levels of banks simulating per capita GDP. In our analysis we simulate correlated bank loan loss provisions and compare these to bank capital buffers. The bank level losses are then aggregated to the financial system level.

We choose a time horizon of three-years to reflect the fact that banks may be unable to recapitalise for such an extended period during severe economic downturns and capital buffers should be able to cover multi-period losses (compare Kupiec and Ramirez, 2013). For the simulation study, we use the latest period (2014:Q4) of the APRA data for both the model estimated with APRA data and the model estimated with annual data. Note that 19 banks remain in the APRA sample at the end of 2014 (while 25 banks were in the sample at the start). The count reduction is due to mergers. For example, Adelaide Bank and Bendigo Bank formed a new company (namely Bendigo and Adelaide Bank) in November 2007 and the Commonwealth Bank of Australia (CBA) acquired Bank West in 2008 while St George merged with Westpac in the same year. In other words, we include both entities before the merger and the combined entity thereafter in our estimation sample. ${ }^{16}$

Next, we obtain the standard deviations of $\varepsilon_{t+1, \tau}$ and $\varepsilon_{i, t+1, \tau}$, total assets and capital buffer for each bank. Since the annual data does not have detailed information about the banks' regulatory capital we apply the values computed for the APRA sample as of 2014:Q4 to those in the annual sample. In particular, we apply the capital buffers and total assets for the 19 banks from the APRA sample to the annual sample.

\footnotetext{
${ }^{16}$ Further, we have interpolated the values for gross loans and assets during periods of mergers to control for related changes. An alternative assumption would be the exclusion of the target firm from the sample and leads to consistent results.
} 
Table 2 displays the descriptive statistics for the main variables of interest for the APRA dataset and annual dataset for the full sample in Panel A and the Pearson correlation matrix of these variables in Panel B. From Column I of Panel A, the annualised loss rate averages at $0.29 \%$ per year. Loan growth is measured as the annualised percentage change in loans relative to the previous year. We report the annualised loan growth for the two-year lag as $11.45 \%$. The capital ratio is defined as total equity to total assets and has a mean of $9.94 \%$.

Panel B shows that the correlation coefficient of 0.42 between CAP and PROFIT is moderate. To avoid the multicollinearity problem, we run the mixed models including both CAP and PROFIT, and one variable at a time ${ }^{17}$. The results are consistent and we report the estimation results using the PROFIT variable, as it is less correlated with other factors, such as $D E P$ and $S I Z E$.

\section{(insert Table 2 about here)}

We compare the statistics of the sample banks in both data sets for 2014 to ensure that both data sets are comparable. From Panel C, it can be seen that both samples are comparable and that both data sets have the same sample size of 19 banks for the simulation. We simulate the realisations for $\varepsilon_{t+1, \tau}$ and $\varepsilon_{i, t+1, \tau}$ based on one million iterations to conduct several sensitivity analyses. As described in Section 3.2, we relate both the banks' loss rates and capital buffers to total assets for consistency in the simulation process. Both observed and regulatory capital levels are often defined as fractions of total risk-weighted assets as in the proposals made by the Basel Committee on Banking Supervision. Hence, we calculate the risk-weighted asset (RWA) density ratio to convert our computed capital buffers to the definitions adopted to the regulatory framework. The density ratio is expressed as the fraction of RWA to total assets. Note that this additional computation is used to facilitate our interpretation of results, and that we use the excess capital to total assets ratio in all the estimation and simulation steps.

We develop an economic framework, where bank default occurs if losses exceed capital buffers and regulatory capital releases (compare Merton, 1974). Capital buffers (CAP_BUFFER) and the regulatory capital threshold are reported by APRA in 2014:Q4. Conditional on the simulated values of $\varepsilon_{t+1, \tau}$ and $\varepsilon_{i, t+1, \tau}$, we compute the values for the loss

\footnotetext{
${ }^{17}$ The robustness checks lead to similar residual parameters.
} 
per bank and the loss of the financial system (that is, the sum of all positive losses). We then compute the various measures for unconditional loss by analysing moments of the distributions. These loss measures are based on one million iterations for the sample banks, using APRA and annual data. These numbers are sufficient to ensure convergence, i.e., the simulated Value-atRisk changes by less than $0.1 \%$ if the data sample is doubled. This results in simulated losses, which we aggregate by value weighting with total assets and summing over the sample banks.

Bank $i$ in period $\tau$ fails if losses exceed the capital buffer:

$$
D_{i, t+1, \tau}=1 \Leftrightarrow \underbrace{\gamma \varepsilon_{t+1, \tau}+\delta \varepsilon_{i, t+1, \tau}}_{\text {shock=unexpected loss rate }}>C A P_{-} B U F F E R_{i, t+1}
$$

Note that this is an important consideration, as in a going concern scenario, a bank is required to continue to meet the regulatory capital requirements. Losses in excess of the capital buffer would have to be covered by investors or other stakeholders including the broader society. Further, it is worth noting that we analyse the unexpected shock that represents the components that banks do not provide provisions for ex-ante (i.e., $\gamma \varepsilon_{t+1, \tau}+\delta \varepsilon_{i, t+1, \tau}$ ) and are not explained by observable bank characteristics. This is the total unexpected shock, which is comprised of two sources of risk: $\varepsilon_{t+1, \tau}$ (i.e., systemic risk) and $\varepsilon_{i, t+1, \tau}$ (i.e., bank-systematic risk). The banks' unexpected shock is usually associated with borrower characteristics that can lead to bank default. Although we would expect that the banks would receive government social support (which we measure in the following) if their capital buffers were depleted, they would not be allowed to operate if the capital level were below the minimum requirement.

Loss exceedances are weighted by total assets $\left(T A_{i, \tau}\right)$ and aggregated to gauge systemwide losses:

$$
L_{i, t+1, \tau}=\sum_{i=1}^{J} T A_{i, t+1} \cdot\left(\gamma \varepsilon_{t+1, \tau}+\delta \varepsilon_{i, t+1, \tau}-C A P_{-} B U F F E R_{i, t+1}\right)
$$

We assume that banks provision for the anticipated loss rate $\left(\alpha_{i}+\beta X_{i, t}\right)$ and that the realised shock to the loss rate $\left(\gamma \varepsilon_{t+1, \tau}+\delta \varepsilon_{i, t+1, \tau}\right)$ is netted with the capital buffer. Note that we only consider the positive losses in excess of the capital buffer. We interpret these as losses the bank is unable to bear on its own as a going concern scenario as a bank is required to 
continue to meet the regulatory capital requirements. In other words, such a bank would have to rely on external support to survive, which may include contributions from investors or other stakeholders.

As a result, we compute the following loss measures for the simulated loss vector: (i) unconditional Value-at-Risk (VaR) and (ii) unconditional Expected Shortfall (CVaR). The Value-at-Risk (VaR) refers to a quantile of the loss distributions. For instance, a 99.9\% VaR of a loan portfolio is the loss value such that a greater loss would only happen in $0.1 \%$ of all cases. The Expected Shortfall (CVaR) is defined as the expectation of losses exceeding VaR. These are the VaR and CVaR of the system wide losses and are measured in absolute terms. We refer to these measures as proxies for systemic risk.

\subsection{Analysis of the loss rate determinants (Stage 1)}

We estimate the loss rates for different time horizons, $\tau$, which are the one-year, the two-year and the three-year horizon using Equation (1). The economic interpretation is that banks may not have access to capital markets in severe economic downturns and hence, can only recapitalise after an extended period of time. We aim to analyse the relevance of bank fundamentals for the estimation of future loss rates.

As the dependent variables relate to the next year, the next two years and the next three years, they enable us to consider losses to the system over different horizons. All loss rates are reported on an annual basis, which is in line with market standards. Table 3 presents the estimation results for the APRA and annual data.

(insert Table 3 about here)

First, we analyse the results for the APRA data ${ }^{18}$. The coefficient on (LIQ) is significantly positive, which suggests that liquid banks are more engaged in riskier loans and hence, resulting in higher future loss rates. The coefficient for the second year lag of loan growth (LOAN_GR) has a positive sign, which is as expected and consistent with Foos et al.

\footnotetext{
${ }^{18}$ The results are consistent if we estimate the models at a yearly frequency using the APRA data (i.e., one observation per bank and year). For robustness, we also run the regressions using non-winsorized data and obtain similar residual parameters for the simulation analysis.
} 
(2010) and Fahlenbrach et al. (2017). In our case, the low economic significance may be explained by the fact that Australian banks are more conservative and have more stringent credit assessment procedures so that the banks are not greatly exposed to low-quality loans.

Another interesting result is that $D E P$ exhibits significantly negative coefficients for all regressions for the APRA data. The negative coefficient for SIZE suggests that bank size is negatively related to loan loss rates. Larger banks, with more deposit funding, are less risky and are exposed to lower losses than smaller banks. Further, large banks often hold a more diversified portfolio, and hence, are able to reduce their idiosyncratic shock and exposure to credit losses. Moreover, we observe a negative effect on future loss rates from the introduction of IFRS in 2005. This is in line with our expectations. The coefficient of GDP_GR is consistently negative (though significant at the $5 \%$ level for the one-year loss prediction). This result implies that banks' loss rates increase during times of distress, supporting the procyclical behaviour of loss provisioning documented in other studies (see e.g., Bikker and Metzemakers, $2005)^{19}$.

Turning to the annual data, it is interesting to see that the signs of the coefficients for bank liquidity, deposit funding and size are reversed when we use the annual data for estimation. The negative coefficient on $L I Q$ is as expected, since banks with more liquid assets would have smaller loan portfolios and thus are less likely to have high credit loss rates. The positive coefficients on DEP and SIZE mean that banks, which are larger and funded by more deposits, are associated with higher future loss rates.

In sum, future loss rates are dependent on current loan losses, banks' overall risk characteristics and the market's credit condition. We find that future credit loss rates are positively associated with lagged loan growth, implying that banks increase their credit impairment charge for new loans supplied. Our results are in line with those found in Laeven and Majnoni (2003) and Bikker and Metzemakers (2005). Further, we find support to the argument by Danielsson (2002) and Hess et al. (2009), in which the estimates gained with

\footnotetext{
${ }^{19}$ Given that the GDP growth rate (GDP_GR) and the change in the rate of employment (UNEMP_GR) are both indicators of the cyclical state of an economy (Hess et al., 2009), we use the GDP growth rate for the main baseline results, and include the unemployment rate as a robustness check. In an unreported table, the coefficient UNEMP_GR is significantly positive and is in line with our prior expectations. When unemployment increases, borrowers are more likely to default on the loans and hence, banks would experience higher numbers of loan defaults and greater loss rates in subsequent periods. The significance of UNEMP_GR is reduced when the GDP growth rate is also taken into account. In summary, our main results are robust to the use of different model specifications and variables.
} 
longer time series and inclusion of the downturn may differ from the ones based on banks' factors in the normal times.

We show the performance of the model for predicting future loss rates in Figure 3 and Figure 4 for the APRA and annual data, respectively. Note that loss rates relate to the start of the reference period. The predicted line tends to understate the observed losses during economic downturns. This implies that by relying on banks' internal models to estimate future loss rates, banks under-charge for losses in times of instability (for example, the GFC in mid2008) and ultimately end up with unexpected losses that exceed the provisioned amount. The results underline the importance of capital buffers so that banks are able to absorb unexpected losses should they occur.

(insert Figures 3 and 4 about here)

\subsection{Analysis of the Australian financial system resilience (Stage 2)}

\subsubsection{Roadmap for the research results}

In this section, we explore the value of capital buffers in maintaining the resilience of Australian financial system. This is examined through a number of different tests. Our baseline simulation of the system losses utilises the actual capital buffers of banks reported in 2014:Q4, and is based on the $99.9 \%$ confidence level and a three-year risk horizon ${ }^{20}$. From this baseline simulation, we conduct several sensitivity tests. It is worth noting that for each sensitivity analysis we only change one parameter at a time to study the impact of that element on the system loss. Firstly, we vary the confidence interval between $95 \%$ and $99.995 \%$, while other parameters remain unchanged. This is to study the sensitivity of the system losses to varying levels of confidence. The remaining tests are based on the $99.9 \%$ confidence interval, as in the baseline simulation.

Secondly, we examine the effects of capital buffers on the system loss. To do this, we replace the banks' actual capital buffers with a set of hypothetical capital buffers (ranging from $0.25 \%$ to $5 \%$ ), while holding other inputs constant. Unlike the actual capital buffers, the hypothetical buffers are fixed across all banks. The interpretation is to observe the system loss

\footnotetext{
${ }^{20}$ We choose to use the $99.9 \%$ confidence level in the baseline simulation, as it is consistent with the InternalRatings Based (IRB) approach in Basel III.
} 
if all banks in the Australian banking system were to hold the same fixed capital buffer. Note that all hypothetical buffers in tables, charts and analyses are expressed in terms of RWA.

Thirdly, we extend the analysis on the impact of capital buffers by looking at the hypothetical capital buffers in addition to actual capital buffers. That is, we set the capital buffers to be the sum of actual capital buffers and a range of hypothetical increments. This is to answer the question: If banks were to hold an additional capital cushion on top of their existing level, how would that impact system losses?

Fourthly, we analyse the impact on the financial system losses when the banks hold just the minimum required capital buffers and no further capital.

\subsubsection{Simulation results}

I. Baseline results and sensitivity to the confidence levels.

Table 4 describes the empirical distribution for the exceedance ratio (i.e., the number of instances where the capital buffer is insufficient to cover excess losses over all iterations) and the loss measures for the financial system, using a set of different confidence levels. The simulated loss measures are based on the actual capital buffers of the 19 Australian ADIs in the sample in 2014. In Table 6, Panel A displays the simulated results for the APRA data and Panel B displays the results for the annual data.

\section{(insert Table 4 about here)}

Using the APRA data, the mean CVaR for the Australian banking system is $\$ 175.4$ million $^{21}$ for the $99.9 \%$ confidence interval. The number reflects the tail of the simulated distribution of aggregated loss exceedances given the state of banks and the economy in 2014:Q4. The CVaR measure is higher for annual data than for the APRA data as it includes the economic downturn in 1991. The mean $\mathrm{CVaR}$ for the financial system is $\$ 6.5$ billion for the $99.9^{\text {th }}$ percentile. This is due to the banking crisis, which translates into greater estimates for $\gamma^{22}$. Similarly, this is also the reason why the simulated risk measures using the annual

\footnotetext{
${ }^{21}$ Note that all the reported numbers for VaRs and CVaRs are based on Australian dollars in 2014.

${ }^{22}$ We have tested the residuals, $\varepsilon_{t+1 \rightarrow \tau}$ and $\varepsilon_{i, t+1 \rightarrow \tau}$ from the Stage 1 estimation for normality (null hypothesis) using a Kolmogorov-Smirnov test. For the three-year horizon, the p-values are 0.091 (APRA data) and 0.047
} 
sample are generally higher than the ones obtained using APRA data. We also report the proportions of exceedances over the one million iterations ${ }^{23}$. For the $99.9 \%$ confidence level, on average 0.0001 and 0.002 banks fail for APRA and annual data, respectively. These exceedance ratios are broadly in line with the confidence levels imposed by the regulators. It is important to note that the exceedance ratios are identical for different confidence intervals. Moreover, in some cases we obtain positive CVaRs whilst the VaR measures are zero. This is of no concern as $\mathrm{VaR}$ is based on the probability level while the expected shortfall is the average of all losses exceeding VaR. However, CVaR increases with the confidence level as fewer zero loss scenarios are included.

We conduct a robustness check to ensure that the difference between annual and APRA data can be attributed to the experience of an economic downturn in 1991. We have restricted the annual data to the period 2002:2014 and re-estimated the models which resulted in a $\gamma=0.056$ and a $\delta=0.100$ and are lower than $\gamma=0.190$ and a $\delta=0.124$ for the full sample. The simulation of system losses results in a $99.9 \% \mathrm{VaR}$ of zero and a $99.9 \% \mathrm{CVaR}$ of $\$ 50,448$ which is substantially smaller than for the full sample reported in Table 4.

As a further robustness check, we repeat the simulation study using five million iterations. This is to ensure that our simulation results satisfy the convergence criteria. Our results remain quantitatively the same, confirming that the choice of one million iterations is sufficient to simulate robust loss measures.

\section{Impact of hypothetical capital buffers}

Figure 5 shows the negative relation between the capital buffers and banks' loss distributions using APRA (first chart) and annual data (second chart). The pattern is consistent with our expectations since increases in capital buffers allow banks to become more resilient. Therefore, the system VaRs become smaller and eventually diminish to zero beyond a certain level of capital buffers. A similar pattern can also be found when we examine the relation between the exceedance ratio and the capital buffers. The higher the capital buffer, the lower the exceedance ratio. The loss measures are generally higher for annual data than for the APRA data, as the latter has been calibrated to the economic downturn in 1991. At a capital buffer of $2.5 \%$, the simulated CVaRs for the APRA and annual data sets are approximately $\$ 4.8$ billion

\footnotetext{
(annual data) for $\varepsilon_{i, t+1 \rightarrow \tau}$ and 0.010 (APRA and annual data) for $\varepsilon_{t+1 \rightarrow \tau}$. As a result, we reject normality in some instances and $\varepsilon_{i, \mathrm{t}+1 \rightarrow \tau}$ is more normal than $\varepsilon_{\mathrm{t}+1 \rightarrow \tau}$. This is in line with our prior expectation that normality may not strictly hold in the time series. However, heavy tails may suggest much lower p-values.

${ }^{23}$ The exceedance ratio is the likelihood of default, which ranges between zero and one.
} 
and $\$ 27.9$ billion, respectively. The higher number for the annual data is due to the inclusion of the banking crisis, which drives the magnitude of these values. For higher capital buffer levels above $1.75 \%$, the diminishing pattern in the risk measures for the APRA data is steadier relative to the decline as observed for the annual data. Our study estimates the response rate at which the loss dissipates corresponding to an increase in capital buffers.

\section{(insert Figure 5 about here)}

\section{Impact of hypothetical capital buffers in addition to actual capital buffers}

We now analyse hypothetical capital buffers in addition to actual capital buffers and find strong evidence to support our previous findings. Higher capital buffers help banks, and eventually the financial system, to avoid future system losses. Further, the rate at which the loss declines in value is diminishing as capital buffers strengthen. The results support the increase of banks' capital buffers as a means of promoting financial system resilience in Australia. Using the APRA data, the system loss can be mitigated with an additional capital buffer of $2 \%$ on top of the banks' current levels. The results are summarised in Figure 6.

(insert Figure 6 about here)

\section{Impact of minimum capital buffers}

Our next analysis looks at the impact on the financial system losses when the banks hold the minimum required capital buffers. In accordance to the Basel framework, the capital conservation buffer of $2.5 \%$ is applied on all ADIs, while the countercyclical capital buffer is currently set at $0 \%$. For large banks that are classified as domestic systematically important banks (D-SIBs), they are required by APRA to hold an additional $1 \%$ of capital to enhance their loss-absorbing capacity.

In Table 5, we repeat the baseline simulation results under two scenarios. First, we display the results for the current setting in Column I, whereby the D-SIBs hold a total capital buffer of $3.5 \%$ and the remaining banks' capital buffer is $2.5 \%$ of risk-weighted assets. Second, Column II shows the simulated system losses under a future setting, in which the 
countercyclical capital buffer of $2.5 \%$ becomes effective. Hence, the D-SIBs and smaller banks will hold $6 \%$ and $5 \%$ of risk-weighted assets as their capital buffers, respectively.

(insert Table 5 about here)

The results reveal that in the current setting, the conditional system losses are substantial and that the overall financial system would be more susceptible to large losses in the event of market distress. As APRA raises the countercyclical capital buffer from $0 \%$ to $2.5 \%$ of risk-weighted assets in accordance with the new Basel III capital requirements the system-wide losses will significantly reduce. We further highlight the need for banks to increase the level of capital buffers to maintain the resilience of the whole financial system.

Table 6 summarises our main findings. With regard to the controversy on the size of capital requirements, we find support for moderate additional capital levels as proposed by the Bank of England (2016). The capital buffers necessary to mitigate systemic losses are within $5 \%$ and hence, within the level of buffers provided by the capital maintenance buffer and the countercyclical capital buffer. Hence, only minor increases should be necessary.

(insert Table 6 about here)

\subsection{Sub-sample results for IRB and non-IRB banks}

In this section we divide the sample banks into two groups, banks that apply the InternalRatings-Based (IRB banks) approach under Basel and non-IRB banks, and examine their ability to absorb loan losses. Cummings \& Durrani (2016) list five of the largest banks that apply the IRB approach and find that these banks provide lower general provisions. The result for our study would be that IRB banks might experience a greater shock in economic downturns.

As reported in Panel A of Table 7, non-IRB banks hold higher capital levels relative to their counterparts. The non-IRB banks are generally smaller in size, hold higher capital buffers and are less profitable. In the fourth quarter of 2014, an average IRB bank holds about $4.64 \%$ while a non-IRB bank holds $7.92 \%$ of capital buffers in excess of their regulatory capital 
requirement (in terms of risk weighted assets). The difference in capital buffers between the two groups is $3.27 \%$ (significant at the 5\% level) for 2014:Q4. Due to the concentration and importance of the large IRB banks in the financial system, their failure can dampen the effect of the capital buffer on system loss more markedly. The RWA density ratios of the two bank groups are relatively similar, which averages of about $65 \%$.

\section{(insert Table 7 about here)}

We report the simulation results for two sub-groups in Panel B. First, we present the baseline results for the APRA and the annual data. Given that the annual data includes the downturn period, the loss measures in Column II are higher than those in Column I. We highlight again the need to include the economic downturn data in the analyses of bank losses.

Turning to the comparison between the two sub-bank groups, it is evident that IRB banks contribute to a larger system loss. For the annual data, the system CVaRs are \$6.4billion and \$104 million for IRB banks and non-IRB banks, respectively. ${ }^{24}$

One could argue that the result is driven by their size differential as the IRB banks are larger (accounting for about $\$ 2.5$ trillion in total assets, while non-IRB banks' assets accumulate to about $\$ 300$ billion) and hence, are more systemically important. To control for this size effect, we set the sum of total assets for the non-IRB banks equal to that of the IRB banks. That is, both groups have a hypothetical level of total assets of $\$ 2.5$ trillion. We then divide this total by 14 banks in the non-IRB group so that each bank is equally weighted. We run the simulation using the APRA and annual data, and report the results in Column III. The results remain qualitatively the same. By having higher total assets, the loss measures for the non-IRB banks increase substantially but they are still lower than those attributed by the IRB banks. Consequently, banks that have higher capital buffers are less likely to cause losses.

In summary, our findings indicate that the losses coming from banks that use the IRB approach under the Basel requirements are susceptible towards larger losses than those that rely on the non-IRB approach. This result persists when controlling for the size of banks. The

\footnotetext{
${ }^{24}$ There is anecdotal evidence from the US that these numbers reflect the size of losses of a financial system under severe economic stress. The net asset value US Federal Deposit Insurance Corporation (FDIC) dropped by $\$ 73.3$ billion between 2007 and 20.9 billion. Despite many differences between the Australian and US financial systems, one of which is size, these numbers are in line with our expectations based on these numbers.
} 
finding has an important bearing on the equal level playing field across banks and across countries. In particular, large banks usually in big countries may get competitive advantage over small banks in small countries for which IRB approach is too costly to employ. Further, Goodhart (2013) suggests that a way to reduce the systemic losses is to limit the size of a bank to a manageable level, and to classify banks as systematically important financial institutions when their failures could result in large costs both to the taxpayers and the economy. Our results complement the current debate on raising capital buffers and reinforces that the focus of the debate should be on large IRB banks.

\section{The costs and benefits of raising higher capital}

Despite the benefits of having higher capital requirements, the recent debate amongst practitioners and academics has focused on the trade-offs between lower system loss and the costs of higher equity. Apart from lower system losses, another benefit of having a stronger capital base is for banks to improve their credit risk. Banks that have high capital buffers, and lower loss rates are seen to be safer relative to their counterparts and thus, are able to enjoy cheaper cost of debt and equity. However, the cost of equity is greater than the cost of debt and an increase of capital may imply greater total funding costs. Furthermore, funding constraints may imply lower lending volumes.

To shed light on this debate, we test the impact of capital on banks' funding cost and lending activities. For our analysis, we use three proxies for funding costs, including the spread on debt that is refinanced over the next three months $\left(S P R_{-} R F\right)$, spread on total refinanced debt $\left(S P R_{-} T R F\right)$ and the spread on banks' total liabilities $\left(S P R_{-} R D\right)^{25}$. We regress each of the three measures above on capital buffer and other controls using an OLS model ${ }^{26}$. For robustness, we replace the variable $C A P \_B U F F E R$ with the loss rate measure, $L R$, and capital ratio, $C A P$. Unlike the traditional capital-to-asset ratio that does not distinguish among banks with similar capital level but facing different regulatory constraints, the capital buffer directly accounts for the regulatory requirements (Gambacorta and Mistrulli, 2004; Cajueiro et al., 2011). Our expectation is that higher capital buffers are associated with a lower cost of debt, as there would be a positive association between loan loss rates and funding costs. Regarding the impacts on

\footnotetext{
${ }^{25}$ Note that the observations for the estimation model of refinanced debt are low due to the fact that banks only started to report refinanced liabilities from 2008 onwards. The detailed information about banks' repriced debt is only available from APRA. In addition, the estimation results are robust with and without the bank and time fixed effects.

${ }^{26}$ The explanatory variables are one-quarter lagged, and we cluster the standard errors at the bank and time levels. We confirm that our results using the GMM estimation are similar to those reported.
} 
lending activity, we anticipate a negative association between the capital buffers and the growth in bank lending.

\section{(insert Table 8 about here)}

We report the results for banks' funding costs and lending in Panels A and B of Table 8 , respectively. We obtain a negative and significant coefficient for the lagged capital buffer across all three specifications. The impact is more pronounced for the spread on repriced debt as this looks at the proportion of the loan portfolio that has more interest rate risk exposure to the banks. From Column (2), we find that an increase in the banks' capital buffers is associated with a reduction in the banks' debt financing. The finding is robust with regards to the use of the capital ratio, though the effect is smaller (results are not reported and available on request). Our result is in line with Gambacorta and Shin (2016).

However, one could argue that this is a simplified way to look at the cost of debt since the approach aggregates over repricing details of the debt portfolio. To understand this association further, we use the mid spread on the non-guaranteed Australian bonds (MID_SPR), which were issued over the sample period. A bond yield at any point in time reflects the credit rating and time to maturity of that particular bond, which is may be a cleaner measure to assess the cost of debt financing. The results in Column (4) support our discussion above, whereby the coefficient on capital buffer is negative and statistically significant at the $10 \%$ level. Hence, banks are able to enjoy cheaper funding costs as the capital buffer increases.

Regarding the cost of equity, we are unable to analyse the return on equity as most Australian banks are not publicly listed or have liquid share prices. However, a quick calculation reveals that total funding cost may actually decrease regardless of the cost of equity. Suppose a bank has a capital ratio of $10 \%$, a cost of equity of $10 \%$ and a cost of debt of $5 \%$ and a total cost of funds of $5.5 \%$. A $25 \mathrm{bp}$ decrease in the cost of debt for a one percent increase in capital implies that an additional $5 \%$ in capital results in a new cost of debt of $3.75 \%$ and a maximum total cost of funds of $4.69 \%$ (if the upper bound for the cost of equity remains the same).

However, it might be that banks with higher capital ratios have difficulties in sourcing their funds and lending volumes are thus lower. Next, we turn to Panel B to examine the effect on bank lending. We examine two aspects of bank lending, including the price (Columns (1) 
and (2)) and loan growth (Columns (3) to (5)). Our proxies for banks' lending rate are the net interest margin on total loans $\left(N I M_{-} T L\right)$, and the spread on loans $\left(S P R_{-} T L\right)^{27}$. Interestingly, the coefficient on lagged capital buffer yields a positive effect on the lending margin proxies, net interest margin and spread on loans. The positive coefficients suggest that there is a positive association between banks' lending margins and capital buffer.

Turning to Columns (3) to (5), we examine the impact of higher capital on the growth rates of total loans ( $\left.L O A N_{-} G R\right)$, commercial loans (CLOAN_GR), and housing loans (HLOAN_GR). Overall, the loan growth is negatively associated with the capital, though the effect is significant for commercial loans (significant at the $10 \%$ level). This is similar to the evidence for Brazilian banks whereby Cajueiro et al. (2011) obtain a negative relation between the capital buffer and loan growth. Given the increase in capital requirements, banks benefit from paying lower debt funding costs but provide lower lending volumes. As a result, the growth in business lending reduces.

\section{Conclusions}

In this paper, we analyse the dynamics of loan loss rates and the interactions of such dynamics on banks' capital buffers and system resilience using a sample of Australian banks over 2002-2014.

Our key findings are as follows. First, we confirm that the inclusion of economic downturns results in higher levels of systemic risk. At the $99.9 \%$ confidence level, the CVaR for the three-year horizon increases from $\$ 175.4$ million to $\$ 6.5$ billion. This indicates that the inclusion of an economic crisis period in the estimation of bank loan losses is crucial. The evidence further suggests that banks that have adopted the IRB approach using recent data do not fully account for the likelihood of financial crises in their internal models, and hence they are holding capital buffers that may be too low. The subsample tests for IRB and non-IRB banks also confirm this finding.

Second, our study provides unique insights regarding the rate at which the loss measures dissipate in response to strengthening capital buffers. It is evident from the research design that higher capital buffers are associated with lower system-wide losses. Banks that hold capital buffers in excess of the regulatory requirement are able to absorb losses more

\footnotetext{
${ }^{27}$ For robustness, we also use other proxies for banks' earnings (for example, return on assets, net interest margin on loans and interest revenue on total loans) and the results are quantitatively similar.
} 
sufficiently, and hence, are less likely to pass the losses onto the whole system. We find that the speed of decline reduces as the capital buffer increases. Given a confidence level of $99.9 \%$ and an additional capital buffer of $2 \%$ (or $5 \%$ for every bank including current capital buffers), the loss would be mitigated.

Third, we shed new light on the debate regarding the trade-off between the benefits and costs of raising capital adequacy requirements. Our results show that a safer level of regulatory capital reduces the risk of bank failures and hence, lowers the cost of banks' debt. However, this is achieved at the expense of reduced loan growth and higher lending rates.

From a policy perspective, our findings are relevant to all economies that did not experience economic downturns after the start of loss data collections (e.g., South East Asian countries where data collection only commenced well after the South East Asian crisis in 1997 and limited loss records are available). Bank regulators could apply our empirical approach to assess the adequacy of capital buffers and the likelihood and magnitude of losses exceeding such buffers to quantify the implied costs for society or to aid the design of more resilient financial systems. We reinforce the argument that higher capital requirements imply a higher level of resilience of the financial system.

These results have to be interpreted with care as they are based on historical data. Further analysis is warranted to assess the impact of the violations of these assumptions and structural changes, which may take place. Despite these challenges we believe that we have set an adequate technical framework to explore the implications of higher capital requirements. Further work on financial system resilience should focus on (i) the reduction of systemic model risk via an improvement of forward-looking loan loss provisioning models, and (ii) optimising the trade-offs between the costs of financial services and higher capital standards that are necessary for reducing losses. We leave these investigations for future work in this area. 


\section{REFERENCES}

Acharya, V.V., Pedersen, L.H., Philippon, T. and Richardson, M., 2017. Measuring systemic risk. Review of Financial Studies 30 (1), 2-47.

Admati, A., and Hellwig, M., 2014. The bankers' new clothes: What's wrong with banking and what to do about it. Princeton University Press, New Jersey.

Adrian, T. and Brunnermeier, M.K., 2016. CoVaR. The American Economic Review 106 (7), $1705-1741$.

Ahmed, A. S., Takeda, C. and Thomas, S., 1999. Bank loan loss provisions: a reexamination of capital management, earnings management and signaling effects. Journal of Accounting and Economics 28, 1-25.

Allen, L., Bali, T. and Tang, Y., 2012. Does systemic risk in the financial sector predict future economic downturns? Review of Financial Studies 25 (10), 3000-3036.

Anufriev, M., and Panchenko, V., 2015. Connecting the dots: Econometric methods for uncovering networks with an application to the Australian financial institutions. Journal of Banking and Finance 61, 241-255.

Ayuso, J., Pérez, D. and Saurina, J., 2004. Are capital buffers pro-cyclical?: Evidence from Spanish panel data. Journal of Financial Intermediation 13 (2), 249-264.

Bank of England, 2016. The Financial Policy Committee's framework for the systemic risk buffer, a consultation paper, January 2016.

Basel Committee on Banking Supervision, 2011. A Global Regulatory Framework for More Resilient Banks and Banking Systems, June 2011.

Basel Committee on Banking Supervision, 2014. Regulatory Consistency Assessment Programme (RCAP) Assessment of Basel III regulations - Australia, March 2014. Bank of International Settlements, Basel.

Bikker, J. A. and Metzemakers, P.A.J., 2005. Bank provisioning behaviour and procyclicality. International Financial Markets, Institutions and Money 15, 141-157.

Borio, C. and Drehmann, M., 2009. Towards an operational framework for financial stability: "fuzzy" measurement and its consequences. BIS Working Paper 284. 
Brownlees, C. and Engle, R.F., 2017. SRISK: A conditional capital shortfall measure of systemic risk. Review of Financial Studies 30 (1), 48-79.

Cajueiro, D., Noronha, A.C. and Tabak, B.M., 2011 May. Bank capital buffers, lending growth and economic cycle: empirical evidence for Brazil. In 2nd BIS CCA Conference on "Monetary policy, financial stability and the business cycle".

Caruana, J., 2012. Building a resilient financial system. Bank of International Settlements, keynote speech at the 2012 ADB Financial Sector Forum on "Enhancing financial stability - issues and challenges" in Manila, 7 February 2012.

Cerutti, E., Claessens, S. and McGuire, P., 2012. Systemic risks in global banking: What can available data tell us and what more data are needed? BIS Working Paper.

Cummings, J. R. and Durrani, K. J., 2016. Effect of the Basel Accord capital requirements on the loan-loss provisioning practices of Australian banks. Journal of Banking and Finance $67,23-36$.

Cummings, J.R. and Wright, S., 2016. Effect of Higher Capital Requirements on the Funding Costs of Australian Banks. Australian Economic Review 49 (1), 44-53.

Danielsson, J., 2002. The Emperor Has No Clothes: Limits to Risk Modelling. Journal of Banking and Finance 26, 1273-96.

Dermine, J. and De Carvalho, C.N., 2008. Bank loan-loss provisioning, central bank rules vs. estimation: The case of Portugal. Journal of Financial Stability 4 (1), 1-22.

Dungey, M.H., Luciani, M. and Veredas, D., 2014. The Emergence of Systemically Important Insurers. CIFR Paper No. WP038, FIRN Research Paper No. 2494030, available at http://ssrn.com/abstract=2494030.

Dungey, M.H., Luciani, M., Matei, M. and Veredas, D., 2016. Surfing through the GFC: Systemic risk in Australia. Economic Record 93(300), 1-19.

El Sood, H.A., 2012. Loan loss provisioning and income smoothing in US banks pre and post the financial crisis. International Review of Financial Analysis 25, 64-72.

Fahlenbrach, R., Prilmeier, R., Stulz, R. M., 2017. Why does fast loan growth predict poor performance of banks? Review of Financial Studies (forthcoming).

Fong, T., Fung, L., Lam, L. and Yu, I., 2011. Measuring the interdependence of banks in Hong Kong, Review of Futures Markets 20 (1), 7-26. 
Foos, D., Norden, L. and Weber, M., 2010. Loan growth and riskiness of banks. Journal of Banking and Finance 34, 2929-2940.

Gambacorta, L. and Mistrulli, P., 2004. Does bank capital affect lending behaviour? Journal of Financial Intermediation 13, 436-457.

Gambacorta, L. and Shin, H.S., 2016. Why bank capital matters for monetary policy. Journal of Financial Intermediation, forth coming.

Goodhart, C., 2013. Ratio controls need reconsideration, Journal of Financial Stability 9 (3), $445-450$.

Heid, F., 2007. The cyclical effects of the Basel II capital requirements. Journal of Banking and Finance 31 (12), 3885-3900.

Hess, K., Grimes, A. and Holmes, M., 2008. An Exploration of Measures to Assess a Bank's Credit Loss Experience', Journal of International Finance and Economics 8, 1-13.

Hess, K., Grimes, A. and Holmes, M., 2009. Credit losses in Australasian banking. Economic Record 85, 331-343.

Kosak, M., Li, S., Loncarski, I., and Marinc, M., 2015. Quality of bank capital and bank lending behavior during the global financial crisis. International Review of Financial Analysis 37, $168-183$.

Kupiec, P. H. and Ramirez, C. D., 2013. Bank failures and the cost of systemic risk: Evidence from 1990 to 1930. Journal of Financial Intermediation 22, 285-307.

Laeven, L. and Majnoni, G., 2003. Loan loss provisioning and economic slowdowns: too much, too late? Journal of Financial Intermediation, 12, 178-197.

Merton, R. C., 1974. On the pricing of corporate debt: The risk structure of interest rates. Journal of Finance 29, 449-470.

Miles, D., Yang, J. and Marcheggiano, G., 2013. Optimal bank capital. The Economic Journal $123,1-37$.

Rodgers, D., 2015. Credit losses at Australian banks: 1980-2013. Reserve Bank of Australia Research Discussion Paper 2015-06.

Roesch, D. and Scheule, H., 2016. The role of loan portfolio losses and bank capital for Asian financial system resilience, Pacific-Basin Finance Journal 40, 289-305. 
Sedunov, J., 2016. What is the systemic risk exposure of financial institutions? Journal of Financial Stability 24, 71-87.

Souza, S.R.S., 2016. Capital requirements, liquidity and financial stability: The case of Brazil. Journal of Financial Stability 25, 179-192.

Thakor, A., 2014. Bank Capital and Financial Stability: An Economic Trade-Off or a Faustian Bargain? Annual Review of Financial Economics 6, 185-223.

Vithessonthi, C., 2016. Deflation, bank credit growth, and non-performing loans: Evidence from Japan. International Review of Financial Analysis 45, 295-305.

Wong, E., Fong, T. and Choi, H., 2011. Procyclicality of loan-loss provisioning and systemic risk in the Hong Kong banking system, Hong Kong Monetary Authority Quarterly Bulletin.

Zhang, Q., Vallascas, F., Keasey, K. and Cai, C.X., 2015. Are Market $\square$ Based Measures of Global Systemic Importance of Financial Institutions Useful to Regulators and Supervisors? Journal of Money, Credit and Banking 47(7), 1403-1442. 


\section{FIGURES}

Figure 1: Total assets and loss rates of the Australian banking system - APRA data (2002:Q12014:Q4) and annual data (1978-2014).

This figure shows the aggregate amount of total assets (in trillions) and the loss rate over time for Australian banks. Total assets are adjusted for inflation as of December 2014. Average quarterly loss rates are annualised and are expressed in percentage per annum. The shaded area represents the period when the markets experience an economic downturn, which is when the annual GDP growth rate was negative. The top chart is for the quarterly sample, and the data is from the Australian Prudential Regulation Authority (APRA). The second chart is for the annual sample, and the data is from banks' public annual reports. The annual data includes consolidated accounts of Australian banks, which implies slightly higher total assets.
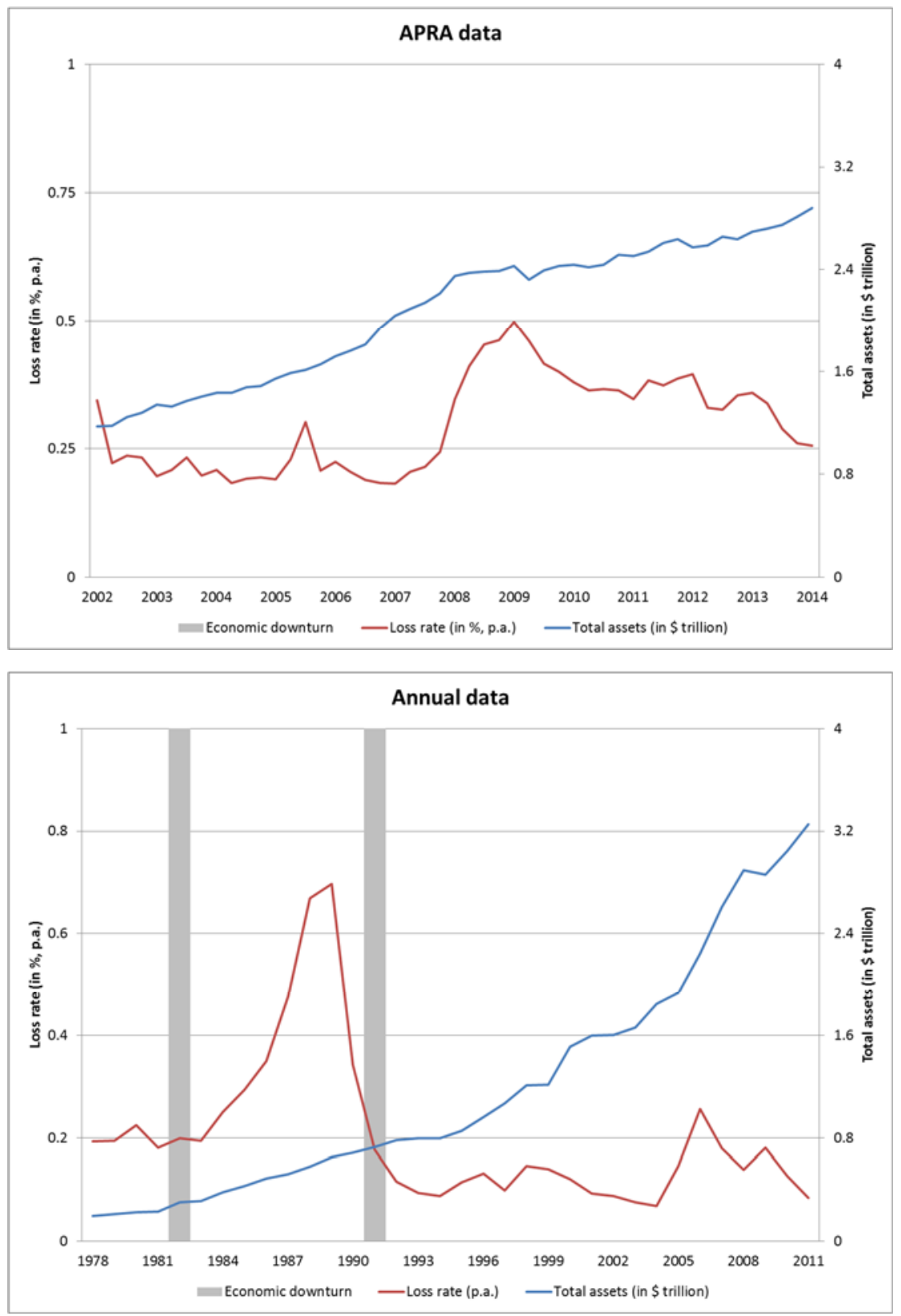
Figure 2: Empirical approach for modelling and simulating banks' loss rates

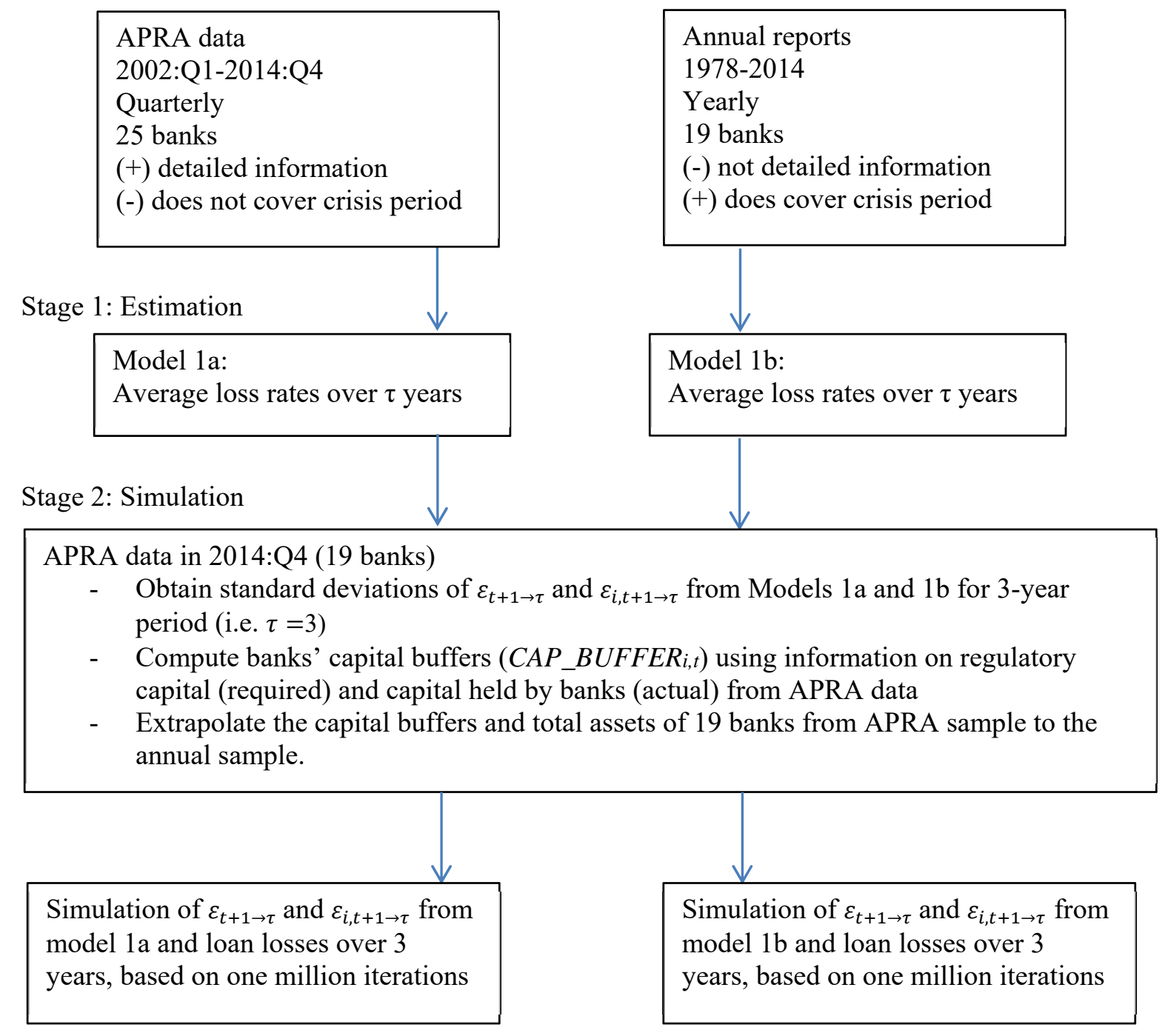


Figure 3: Model predicted and actual loss rate Australian financial system using APRA data (2002:Q1-2014:Q4)

Predicted loss rates are the fitted values that are obtained from model parameters. Actual loss rates are based on banks' realised loss rates. The first chart is for the one-year forward loss rate, followed by the two-year and three-year forward loss rates. Note that the loss rate relates to the start of the reference period.
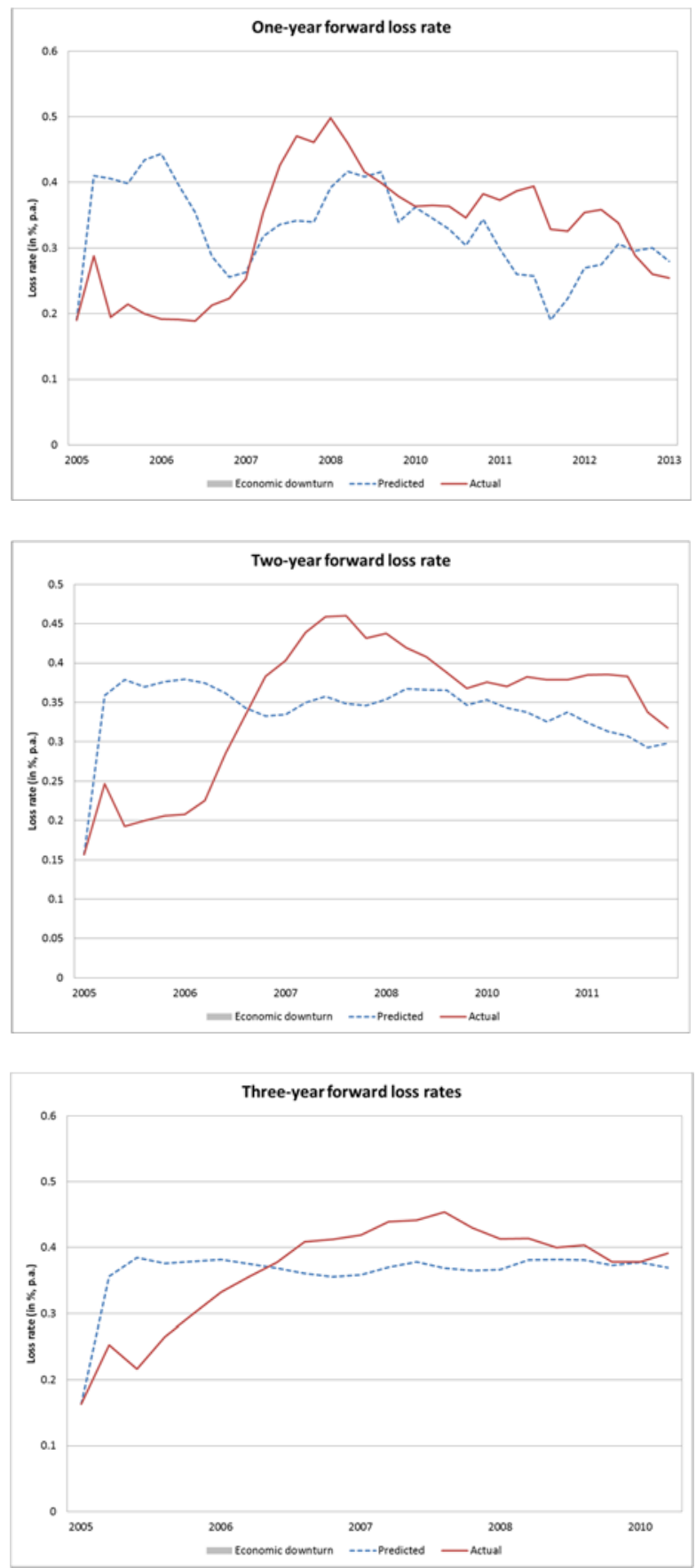
Figure 4: Model predicted and actual loss rate Australian financial system using annual data (1978-2014)

Predicted loss rates are the fitted values that are obtained from model parameters. Actual loss rates are based on banks' realised loss rates. The shaded area represents the period when the markets experienced an economic downturn, which was when the annual GDP growth rate was negative. The first chart is for the one-year forward loss rate, followed by the two-year and three-year forward loss rates. Note that the loss rate relates to the start of the reference period.
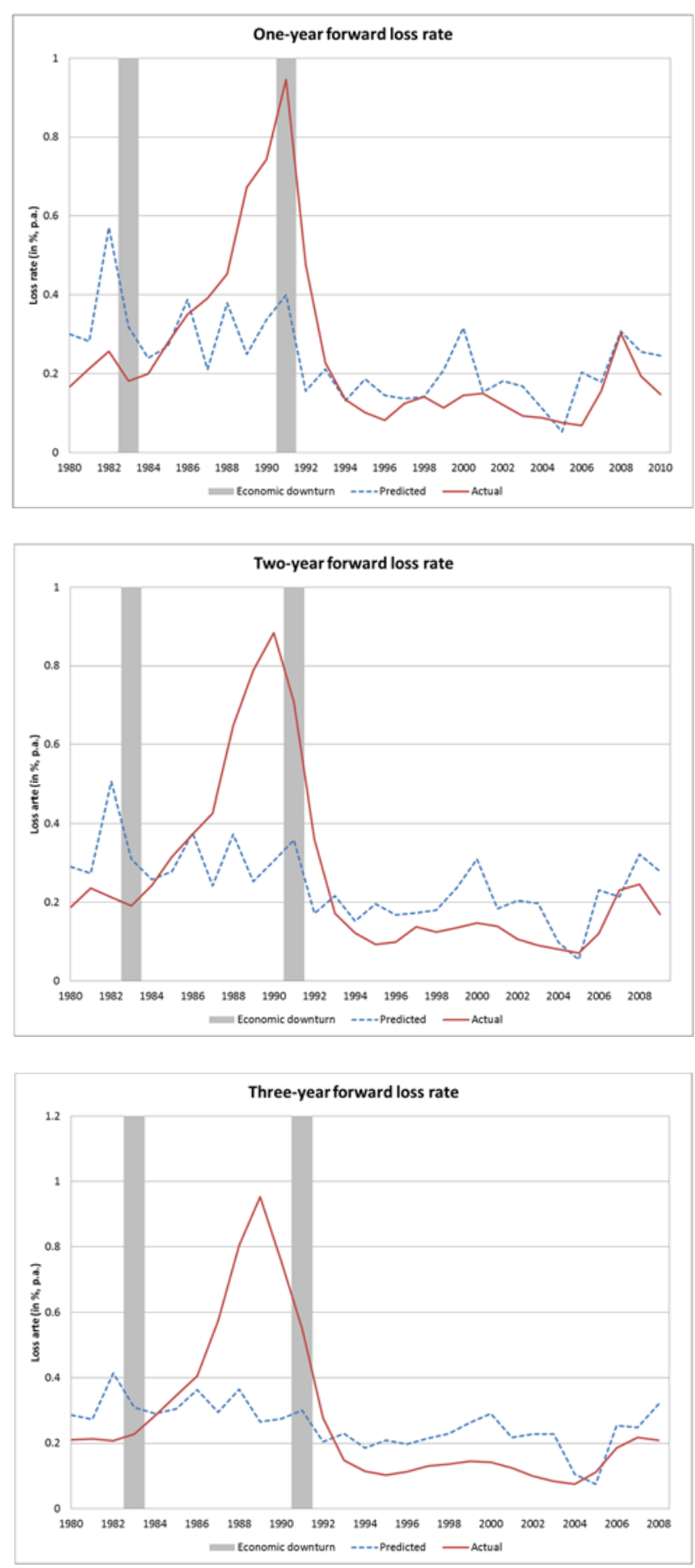
Figure 5: Sensitivity analysis of system resilience measures to hypothetical capital buffers for the Australian financial system - APRA (2002:Q1-2014:Q4) and annual sample (1978-2014)

The figure illustrates the sensitivity of the system resilience measures to varying banks' capital buffers. We replace the actual capital buffers of Australian ADIs as of 2014:Q4 with a set of hypothetical capital buffers (from $0.25 \%-5 \%$ ). Note that the capital buffers are expressed in terms of RWA. The loss measures are based on the $99.9 \%$ Value-at-Risk. System resilience measures are reported in billions of Australian dollars in 2014. The top chart presents the sensitivity for the APRA sample and the second chart is for the annual sample.
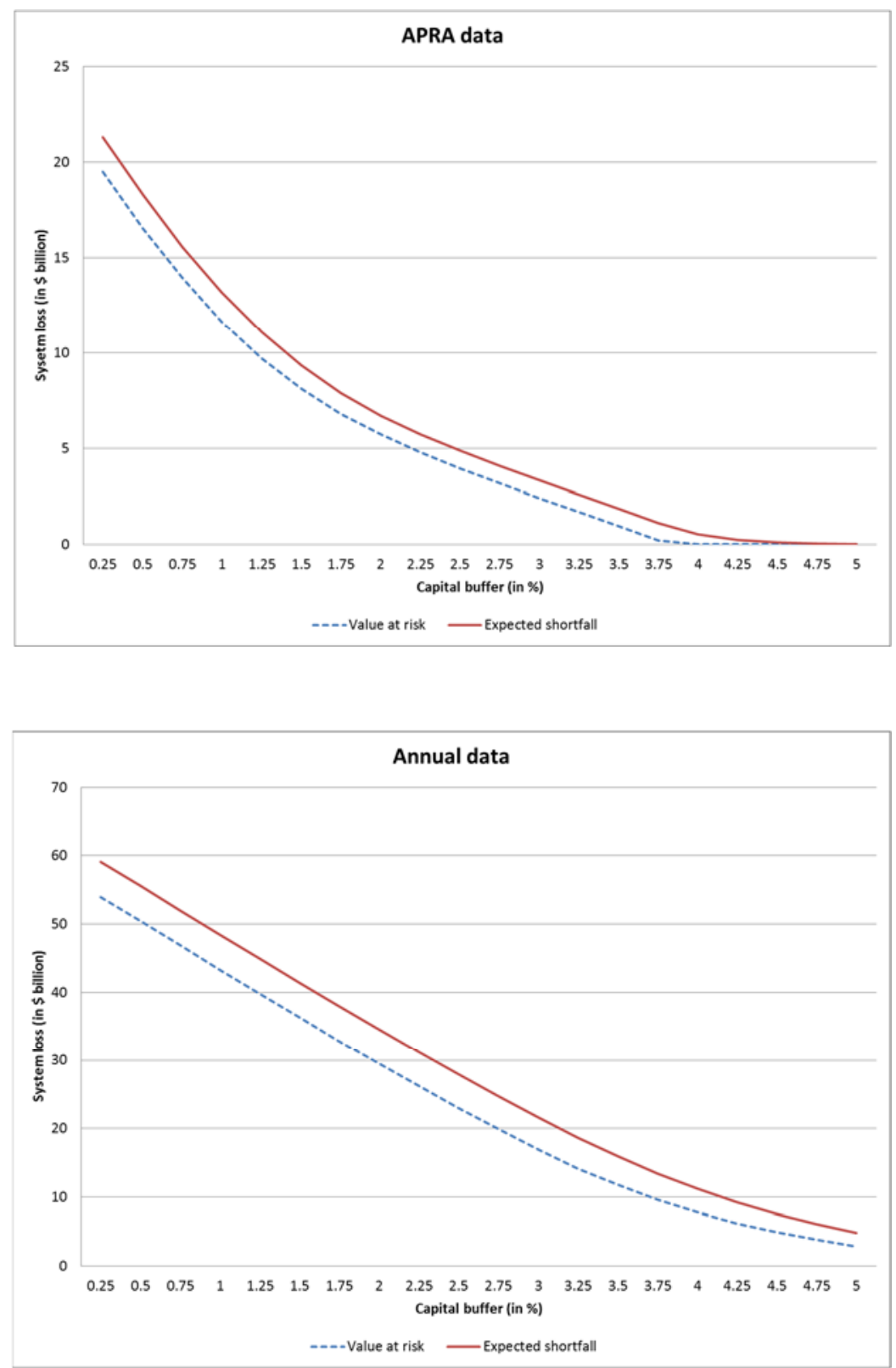
Figure 6: Sensitivity analysis of system resilience measures to hypothetical add-on capital buffers for the Australian financial system - APRA (2002:Q1-2014:Q4) and annual sample (1978-2014)

The figure illustrates the sensitivity of the system resilience measures to banks' hypothetical add-on capital buffers in addition to their actual levels. We raise the actual capital buffers of Australian ADIs as of 2014:Q4 by a set of hypothetical add-on capital buffer cushions (from $0.25 \%-2 \%$ ). We analyse the system loss, in which banks hold additional capital buffers on top of their existing levels. Note that the capital buffers are expressed in terms of RWA. The loss measures are based on the $99.9 \%$ Valueat-Risk. System resilience measures are reported in $\$$ millions and $\$$ billions for the APRA data and annual data, respectively. These measures are in Australian dollars as in 2014. The top chart presents the sensitivity for the APRA sample and the second chart is for the annual sample.
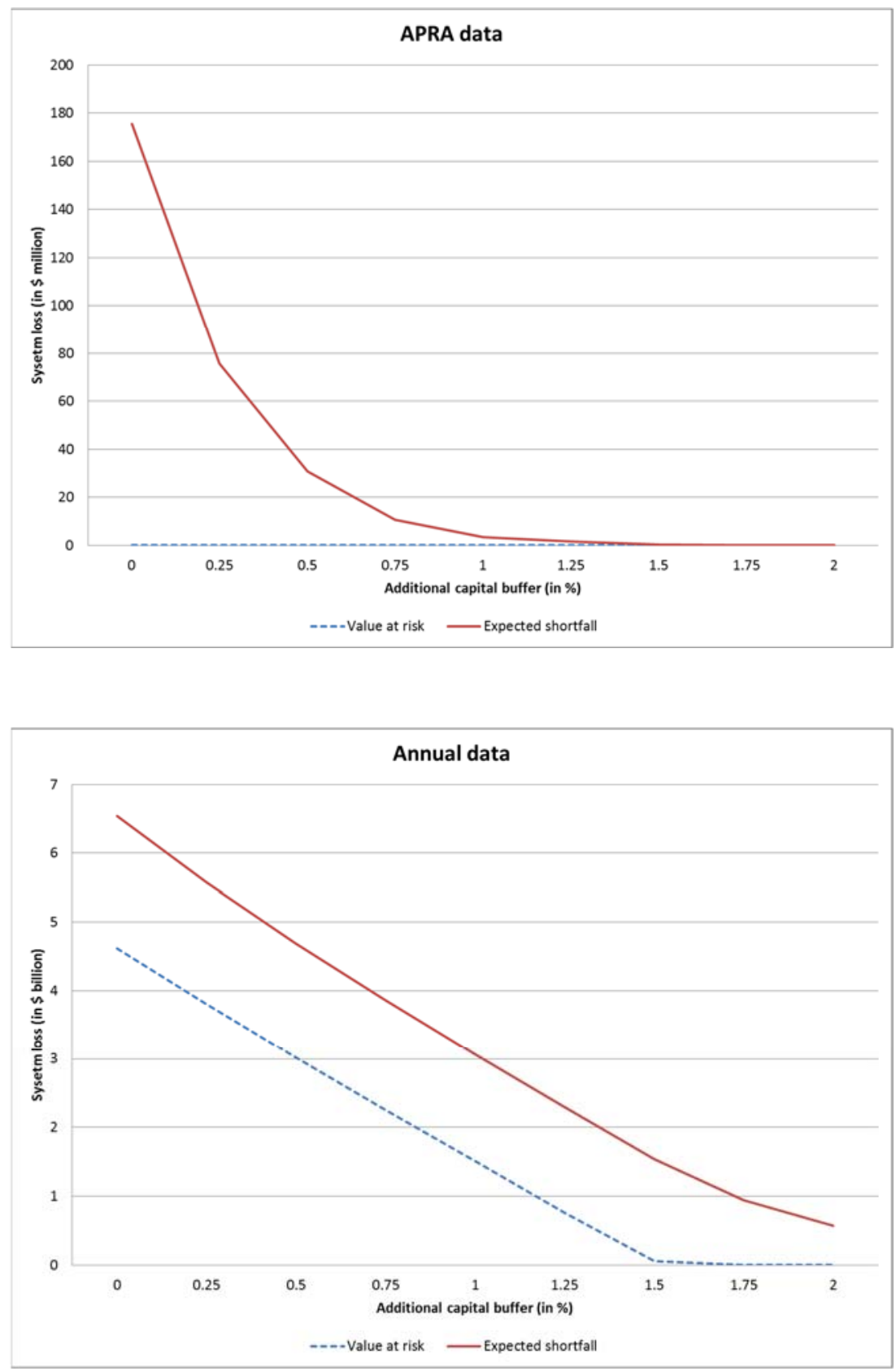


\section{TABLES}

\section{Table 1: Description of variables and data source}

\begin{tabular}{|c|c|c|}
\hline Variables & Definitions & Data source \\
\hline$L R$ & Average loss rate of bank $i$ over one year, two years and three years & APRA, (ARF_330_0_L), annual reports \\
\hline$L O A N \_G R$ & $\begin{array}{l}\text { Two-year lag of loan growth (where current loan growth is calculated as the yearly } \\
\text { moving difference between current loans and last year's loans, scaled by last year's total } \\
\text { assets) }\end{array}$ & APRA (ARF_320_0), annual reports \\
\hline HLOAN & Banks' housing loan ratio (total housing loans to total loans) & APRA (ARF_320_0), annual reports \\
\hline CLOAN & Banks' commercial loan ratio (total commercial loans to total loans) & APRA (ARF_320_0), annual reports \\
\hline CAP & Banks' capital ratio (total equity to total assets) & APRA, ARF_320_0 \\
\hline PROFIT & Banks' profitability (profit before tax and credit impairment charge to total assets) & APRA, ARF_330_0_L \\
\hline TIER_CAP & Banks' observed capital ratio (sum of Tier 1 and Tier 2 capital to total assets) & APRA (ARF_110_0_1), annual reports \\
\hline$R E G \_C A P$ & $\begin{array}{l}\text { Banks' total regulatory capital ratio (total regulatory capital to total assets, where total } \\
\text { regulatory capital is defined as } 8 \text { per cent of total risk-weighted assets) }\end{array}$ & APRA (ARF_110_0_1), annual reports \\
\hline GDP_GR & Current Gross Domestic Product (GDP) growth rate, seasonally adjusted and annualised & ABS \\
\hline UNEMP_GR & Change in unemployment rate, seasonally adjusted and annualised & ABS \\
\hline IFRS & $\begin{array}{l}\text { A binary variable that takes a value of one for periods 2004:Q4 and 2005:Q1 (2004 and } \\
\text { 2005) for APRA data (annual data) }\end{array}$ & Authors' computation \\
\hline$S P R \_R F$ & $\begin{array}{l}\text { Spread on refinanced debt over 3-months (difference between the implied interest rate } \\
\text { and cash rate, where the implied interest rate is calculated as the interest expense over 3- } \\
\text { month refinanced debt) }\end{array}$ & APRA (ARF_330_0_L), \\
\hline
\end{tabular}




\begin{tabular}{|c|c|c|}
\hline$S P R \_T R F$ & $\begin{array}{l}\text { Spread on total refinanced debt over all maturities (difference between the implied } \\
\text { interest rate and cash rate, where the implied interest rate is calculated as the interest } \\
\text { expense over total refinanced debt) }\end{array}$ & APRA (ARF_330_0_L), \\
\hline$S P R \_R D$ & $\begin{array}{l}\text { Spread on refinanced debt over } 3 \text {-months (difference between the implied interest rate } \\
\text { and cash rate, where the implied interest rate is calculated as the interest expense over } \\
\text { total debt) }\end{array}$ & APRA (ARF_330_0_L, ARF_320_0) \\
\hline$M I D \_S P R$ & Mid spread on Australian bonds (excluding guaranteed bond issues) & Bloomberg \\
\hline TTM & Time to maturity of Australian bonds & Bloomberg \\
\hline RATINGS & A set of dummy variables that indicate the Moody's credit ratings of banks' bonds & Bloomberg \\
\hline CLOAN_GR & Annual growth rate of commercial loans & APRA (ARF_320_0), annual reports \\
\hline HLOAN_GR & Annual growth rate of housing loans & APRA (ARF_320_0), annual reports \\
\hline$S P R \_T L$ & Spread on total loans (total interest income over total loans minus the cash rate) & APRA, (ARF_330_0_L) \\
\hline NIM_TL & Net interest margin on total loans (net interest income over total loans) & APRA (ARF_330_0_L) \\
\hline
\end{tabular}




\section{Table 2: Description of variables}

This table presents the summary statistics of the variables used in the study in Panel A. Column I reports the statistics for the APRA data and Column II reports the statistics for the annual data. Panel B presents the Pearson correlation matrix for the variables that are included in the mixed model (1). Panel C reports the summary statistics for APRA and annual data as of 2014. All variables are winsorized at the $5^{\text {th }}$ and $95^{\text {th }}$ percentiles. $* * / * * *$ denote significance at the $5 \%$ and $1 \%$ level, respectively.

\begin{tabular}{|c|c|c|c|c|c|c|c|c|c|c|c|}
\hline \multicolumn{12}{|l|}{ Panel A: Summary statistics } \\
\hline \multirow[b]{2}{*}{ Variable } & & \multicolumn{5}{|c|}{$\begin{array}{l}\text { I. APRA data for the period 2002Q1-2014Q4 } \\
\text { (N=25 banks) }\end{array}$} & \multicolumn{5}{|c|}{$\begin{array}{l}\text { II. Annual data for the period 1978-2014 } \\
\qquad(\mathrm{N}=19 \text { banks })\end{array}$} \\
\hline & & No. of obs & Mean & Std Dev & P5 & P95 & No. of obs & Mean & Std Dev & P5 & P95 \\
\hline One-year loss rate $(\%)$ & LR & 1,093 & 0.29 & 0.32 & 0.00 & 1.18 & 376 & 0.19 & 0.25 & 0.00 & 0.65 \\
\hline Liquidity ratio (\%) & LIQ & 1,093 & 19.30 & 11.16 & 2.88 & 46.23 & 365 & 13.86 & 7.65 & 3.26 & 32.94 \\
\hline Housing loan ratio (\%) & HLOAN & 1,091 & 58.68 & 31.80 & 0.00 & 100.00 & 376 & 60.26 & 22.38 & 21.03 & 99.63 \\
\hline Lagged loan growth (\%) & LOAN_GR & 867 & 11.45 & 15.39 & -12.94 & 49.64 & 335 & 11.62 & 13.07 & -7.67 & 46.38 \\
\hline Deposit funding $(\%)$ & $\mathrm{DEP}$ & 1,093 & 62.54 & 15.97 & 28.44 & 85.39 & 370 & 67.34 & 14.64 & 43.67 & 90.73 \\
\hline Size (in \$billion) & SIZE & 1,093 & 23.49 & 2.20 & 20.06 & 26.97 & 376 & 23.96 & 2.31 & 19.94 & 27.24 \\
\hline Capital ratio (\%) & CAP & 1,093 & 9.94 & 5.63 & 4.62 & 23.77 & 376 & 6.61 & 2.02 & 4.23 & 12.44 \\
\hline Profitability (\%) & PROFIT & 1,093 & 1.55 & 0.94 & 0.31 & 4.12 & 370 & 1.36 & 0.44 & 0.58 & 2.15 \\
\hline GDP growth rate $(\%)$ & GDP_GR & 1,093 & 2.95 & 0.97 & 1.30 & 4.80 & 376 & 3.19 & 1.45 & 0.90 & 5.30 \\
\hline Unemployment growth rate $(\%)$ & UNEMP_GR & 1,093 & -0.05 & 0.59 & -0.60 & 1.40 & 375 & -0.06 & 0.91 & -1.00 & 2.20 \\
\hline
\end{tabular}




\begin{tabular}{|c|c|c|c|c|c|c|c|c|c|c|}
\hline \multicolumn{11}{|c|}{ Panel B: Pearson correlation matrix } \\
\hline & LR & LIQ & HLOAN & LOAN_GR & DEP & SIZE & CAP & PROFIT & GDP_GR & UNEMP_GR \\
\hline LR & 1.00 & & & & & & & & & \\
\hline LIQ & 0.25 & 1.00 & & & & & & & & \\
\hline HLOAN & -0.03 & 0.07 & 1.00 & & & & & & & \\
\hline LOAN_GR & -0.10 & 0.07 & 0.19 & 1.00 & & & & & & \\
\hline DEP & -0.22 & 0.09 & 0.10 & 0.12 & 1.00 & & & & & \\
\hline SIZE & 0.01 & -0.24 & 0.38 & -0.06 & -0.14 & 1.00 & & & & \\
\hline CAP & 0.24 & 0.27 & -0.30 & -0.09 & -0.32 & -0.56 & 1.00 & & & \\
\hline PROFIT & 0.24 & -0.08 & -0.12 & -0.13 & -0.53 & 0.04 & 0.42 & 1.00 & & \\
\hline GDP_GR & -0.17 & -0.06 & -0.03 & 0.02 & 0.07 & -0.06 & 0.02 & 0.04 & 1.00 & \\
\hline UNEMP_GR & 0.17 & 0.08 & 0.05 & -0.12 & -0.05 & 0.07 & -0.01 & -0.05 & -0.53 & 1.00 \\
\hline
\end{tabular}




\begin{tabular}{|c|c|c|c|c|c|c|c|c|}
\hline \multicolumn{9}{|c|}{ Panel C: Summary statistics as of 2014} \\
\hline \multirow[b]{3}{*}{ Variable } & & \multicolumn{3}{|c|}{$\begin{array}{l}\text { I. APRA data as of } 2014 Q 4 \\
(N=19 \text { banks })\end{array}$} & \multicolumn{3}{|c|}{$\begin{array}{l}\text { II. Annual data for } 2014 \\
\qquad(\mathrm{~N}=10 \text { banks })\end{array}$} & \multirow{3}{*}{$\begin{array}{l}\text { III. Difference } \\
\text { (I) - (II) } \\
\text { Mean }\end{array}$} \\
\hline & & \multicolumn{3}{|c|}{ Mea } & \multicolumn{3}{|c|}{ Mea } & \\
\hline & & No. of obs & $\mathrm{n}$ & Std Dev & No. of obs & $\mathrm{n}$ & Std Dev & \\
\hline One-year loss rate $(\%)$ & LR & 19 & 0.25 & 0.34 & 10 & 0.08 & 0.06 & $0.17 * *$ \\
\hline Liquidity ratio $(\%)$ & LIQ & 19 & 19.64 & 8.10 & 10 & 14.91 & 8.77 & $-11.25^{* * *}$ \\
\hline Housing loan ratio $(\%)$ & HLOAN & 19 & 64.13 & 30.87 & 10 & 68.82 & 19.05 & -4.70 \\
\hline Lagged loan growth $(\%)$ & LOAN_GR & 19 & 5.57 & 11.84 & 10 & 5.64 & 15.03 & -0.06 \\
\hline Deposit funding $(\%)$ & DEP & 19 & 65.71 & 14.76 & 10 & 68.72 & 11.07 & -3.02 \\
\hline Size (in \$billion) & SIZE & 19 & 24.01 & 2.14 & 10 & 24.73 & 3.02 & -0.72 \\
\hline Capital ratio $(\%)$ & CAP & 19 & 9.49 & 3.96 & 10 & 7.28 & 1.36 & $2.20 * *$ \\
\hline Profitability (\%) & PROFIT & 19 & 1.29 & 0.67 & 10 & 1.17 & 0.36 & 0.12 \\
\hline GDP growth rate $(\%)$ & GDP_GR & 19 & 2.40 & 0.00 & 10 & 2.40 & 0.00 & 0.00 \\
\hline Unemployment growth rate $(\%)$ & UNEMP_GR & 19 & 0.20 & 0.00 & 10 & 0.20 & 0.00 & 0.00 \\
\hline Total Tier 1 and Tier 2 capital & TIER_CĀP & 19 & 9.75 & 4.23 & - & - & - & - \\
\hline Regulatory capital & REG_CAP & 19 & 5.15 & 1.74 & - & - & - & - \\
\hline Capital buffer (\%) & CAP_BUFFER & 19 & 4.61 & 3.29 & - & - & - & - \\
\hline RWA Density ratio & RWA_DR & 19 & 0.64 & 0.22 & - & - & - & - \\
\hline
\end{tabular}




\section{Table 3: Mixed model results for the bank-level loan portfolio loss rates using APRA data (2002:Q1-2014:Q4) and annual data (1978-2014)}

All variables (except size) are winsorized at the $5^{\text {th }}$ and $95^{\text {th }}$ percentiles. The table shows the parameters estimated from the mixed model (1) for the Australian financial system. The subscript $\tau$ refers to the one, two and three year horizon. $* * * * * * *$ indicate significance at the $10 \%, 5 \%$ and $1 \%$ level, respectively.

$$
L R_{i, t+1, \tau}=\alpha_{i}+\beta X_{i, t}+\gamma \varepsilon_{t+1, \tau}+\delta \varepsilon_{i,+1, \tau}
$$

\begin{tabular}{|c|c|c|c|c|c|c|}
\hline \multirow{2}{*}{ Dependent variable } & \multicolumn{3}{|l|}{ APRA data } & \multicolumn{3}{|l|}{ Annual data } \\
\hline & One-year & Two-year & Three-year & One-year & Two-year & Three-year \\
\hline LIQ & $0.0051 * * *$ & $0.0055 * * *$ & $0.0048 * * *$ & -0.0032 & $-0.0038^{*}$ & $-0.0040 * *$ \\
\hline \multirow[t]{2}{*}{ HLOAN } & -0.0026 & 0.0028 & $0.0037 * *$ & $-0.0049 * * *$ & $-0.0043 * * *$ & $-0.0036^{* * *}$ \\
\hline & $(0.0020)$ & $(0.0020)$ & $(0.0019)$ & $(0.0011)$ & $(0.0010)$ & $(0.0009)$ \\
\hline \multirow[t]{2}{*}{ DEP } & $-0.0052 * * *$ & $-0.0043^{* * *}$ & $-0.0046^{* * *}$ & $0.0021 *$ & $0.0023 * *$ & $0.0021 * *$ \\
\hline & $(0.0010)$ & $(0.0009)$ & $(0.0009)$ & $(0.0012)$ & $(0.0010)$ & $(0.0012)$ \\
\hline \multirow[t]{2}{*}{ SIZE } & $-0.1818 * * *$ & $-0.1531 * * *$ & $-0.1080 * * *$ & $0.0481 *$ & $0.0573 * *$ & $0.0601 * *$ \\
\hline & $(0.0320)$ & $(0.0314)$ & $(0.0284)$ & $(0.0247)$ & $(0.0242)$ & $(0.0240)$ \\
\hline PROFIT & -0.0202 & $-0.0274 *$ & $-0.0399 * * *$ & -0.0087 & -0.0098 & -0.0171 \\
\hline \multirow[t]{2}{*}{ IFRS } & $-0.2120 * *$ & $-0.1985 * *$ & $-0.1947 * * *$ & -0.1151 & -0.1461 & -0.1514 \\
\hline & $(0.1076)$ & $(0.0934)$ & $(0.0626)$ & $(0.1336)$ & $(0.1429)$ & $(0.1547)$ \\
\hline$\gamma$ & 0.094 & 0.081 & 0.050 & 0.174 & 0.189 & 0.206 \\
\hline$\delta$ & 0.209 & 0.182 & 0.150 & 0.168 & 0.146 & 0.131 \\
\hline Bank-specific intercept & $\mathrm{Y}$ & $\mathrm{Y}$ & $\mathrm{Y}$ & $\mathrm{Y}$ & Y & Y \\
\hline No. of obs & 767 & 669 & 573 & 313 & 295 & 278 \\
\hline
\end{tabular}




\section{Table 4: Simulated system resilience measures and confidence intervals}

The table shows a sensitivity analysis of the system resilience measures to varying confidence intervals. The resilience measures are computed for a range of confidence intervals (from 95\% to 99.995\%) and are based on one million iterations. This simulation uses actual capital buffers of Australian ADIs as of 2014:Q4, and the three-year loss model. The highlighted baseline simulation assumes the $99.9 \%$ confidence level. The exceedance ratio is the number of loss exceedances over the number of iterations. VaR is the Value-at-Risk and CVaR is the conditional VaR (known as Expected Shortfall). The system resilience measures are reported in Australian dollars in 2014. Panel A and Panel B report the system resilience measures for the APRA and annual samples, respectively.

\begin{tabular}{|c|c|c|c|}
\hline \multicolumn{4}{|c|}{ Panel A: Systemic risk measures using APRA data } \\
\hline Confidence interval (\%) & Exceedance ratio & Systemic VaR (\$) & Systemic CVaR (\$) \\
\hline 95.000 & 0.0001 & - & $3,508,598$ \\
\hline 99.900 & 0.0001 & - & $175,429,877$ \\
\hline 99.925 & 0.0001 & - & $233,906,503$ \\
\hline 99.950 & 0.0001 & - & $350,859,754$ \\
\hline 99.975 & 0.0001 & - & $701,719,508$ \\
\hline 99.995 & 0.0001 & $1,276,791,819$ & $2,059,435,102$ \\
\hline \multicolumn{4}{|c|}{ Panel B: Systemic risk measures using Annual data } \\
\hline Confidence interval (\%) & Exceedance ratio & Systemic VaR (\$) & Systemic CVaR (\$) \\
\hline 95.000 & 0.0016 & - & $446,747,296$ \\
\hline 99.900 & 0.0016 & $4,620,834,645$ & $6,539,793,576$ \\
\hline 99.925 & 0.0016 & $5,148,179,608$ & $7,087,042,573$ \\
\hline 99.950 & 0.0016 & $5,888,996,887$ & $7,880,463,959$ \\
\hline 99.975 & 0.0016 & $7,207,894,214$ & $9,268,513,665$ \\
\hline 99.995 & 0.0016 & $10,650,966,361$ & $12,784,423,214$ \\
\hline
\end{tabular}




\section{Table 5: Sensitivity analysis of system resilience measures to minimum capital buffers}

The table shows the simulation results for both APRA data and annual data in the current and future implementation of capital buffers. In Column I, the simulation uses current implementation, whereby we apply the capital buffers of $2.5 \%$ and $3.5 \%$ of risk-weighted assets for non-DSIBs and D-SIBs as of 2014:Q4, respectively. In Column II, we consider the future implementation of a countercyclical capital buffer of $2.5 \%$ on top of the existing capital conservation capital. Hence, we apply the capital buffers of 5\% and 6\% of risk-weighted assets for non-DSIBs and D-SIBs as of 2014:Q4, respectively. Note that the capital buffers are expressed in terms of RWA. The system resilience measures are based on the $99.9 \%$ confidence interval and one million iterations, using the threeyear loss rate model. CVaR is the conditional VaR (known as Expected Shortfall). The system resilience measures are reported in Australian dollars in 2014.

\begin{tabular}{|c|c|c|c|c|}
\hline \multicolumn{5}{|c|}{ Simulation results for the current and future implementation of capital requirements } \\
\hline & \multirow{2}{*}{\multicolumn{2}{|c|}{$\begin{array}{c}\text { I. Current implementation } \\
\text { Non D-SIBs }(2.5 \%) \& \text { D-SIBs }(3.5 \%) \\
\end{array}$}} & \multirow{2}{*}{\multicolumn{2}{|c|}{$\begin{array}{c}\text { II. Future implementation } \\
\text { Non D-SIBs }(5 \%) \& \text { D-SIBs }(6 \%)\end{array}$}} \\
\hline & & & & \\
\hline & APRA & Annual & APRA & Annual \\
\hline Exceedance ratio & 0.0024 & 0.0217 & 0.0000 & 0.0004 \\
\hline Systemic VaR (\$) & $937,207,746$ & $12,696,450,148$ & - & $99,381,452$ \\
\hline Systemic CVaR (\$) & $1,852,380,192$ & $17,050,504,418$ & 301,994 & $1,289,382,853$ \\
\hline
\end{tabular}




\section{Table 6: Summary of the simulation results}

The table shows the main simulation results for both APRA data and annual data. In Column I, the simulation uses actual capital buffers of Australian ADIs as of 2014:Q4. In Column II, we replace the actual capital buffers of Australian ADIs as of 2014:Q4 by a set of hypothetical capital buffers (from 0.25\%-5\%). In Column III, we raise the actual capital buffers of Australian ADIs as of 2014:Q4 by a set of hypothetical incremental capital cushion (from 0.25\%-2\%). Note that the capital buffers are expressed in terms of RWA. The system resilience measures are based on the $99.9 \%$ confidence interval and one million iterations, using the three-year loss rate model. CVaR is the conditional VaR (known as Expected Shortfall). The system resilience measures are reported in Australian dollars in 2014.

\begin{tabular}{llll}
\hline Data/ Capital buffer & Actual (baseline) & Hypothetical $(0.25 \%-5 \%)$ & Actual + hypothetical $(0 \%-2 \%)$ \\
\hline APRA $(\mathrm{CVaR}, 99.9 \%)$ & $\$ 175.4$ million & $\$ 21.3$ billion $-\$ 15.9$ million & $\$ 175.4$ million $-\$ 0$ \\
Annual $(\mathrm{CVaR}, 99.9 \%)$ & $\$ 6.5$ billion & $\$ 59.1$ billion $-\$ 4.8$ billion & $\$ 6.5$ billion $-\$ 345.5$ million \\
\hline
\end{tabular}




\section{Table 7: Robustness checks - IRB banks versus non-IRB banks}

The table shows the summary statistics and the resilience measures of two subsamples, internal-ratings based (IRB) and non-IRB banks. The RWA density ratio is expressed in decimal place and computed as the ratio of total risk-weighted asstes to total assets. The mean capital buffer is calculated as the difference between the observed capital (sum of Tier 1 and Tier 2 capital) and the regulatory capital (expressed in terms of total risk-weighted assets). The system resilience measures are computed for the $99.9 \%$ confidence interval and are based on one million iterations. This simulation uses actual capital buffers of Australian ADIs as of 2014:Q4. The exceedance ratio is the number of loss exceedances over the number of iterations. VaR is the Value-at-Risk and CVaR is the conditional VaR (known as Expected Shortfall). The mean RWA density ratio is count-weighted. Panel A reports the summary statistics for IRB banks and non-IRB banks. Panel B reports the system resilience measures for the APRA and annual samples. The system resilience measures are reported in Australian dollars in 2014.

\begin{tabular}{lcccc}
\hline \multicolumn{5}{c}{ Panel A: Statistics for IRB and non-IRB banks (APRA data as of 2014:Q4) } \\
\hline Sub-sample & No. of obs & Sum of total assets (\$, billion) & RWA density ratio (\%) & Mean capital buffer (\%) \\
\hline IRB banks & 5 & $2,578.69$ & 0.65 & 4.64 \\
Non-IRB banks & 14 & 300.09 & 0.65 & 7.92 \\
\hline
\end{tabular}

\begin{tabular}{|c|c|c|c|c|c|c|}
\hline \multicolumn{7}{|c|}{ Panel B: Simulation results for IRB and non-IRB banks } \\
\hline & \multicolumn{2}{|c|}{ I. Baseline model - APRA } & \multicolumn{2}{|c|}{ II. Baseline model - Annual } & \multicolumn{2}{|l|}{ III. Control for bank size } \\
\hline & IRB banks & Non-IRB banks & IRB banks & Non-IRB banks & Non-IRB banks (APRA) & Non-IRB banks (Annual) \\
\hline Exceedance ratio & 0.0001 & 0.0000 & 0.0030 & 0.0008 & 0.0000 & 0.0008 \\
\hline Systemic VaR (\$) & - & - & $4,562,421,673$ & $56,568,820$ & - & $820,876,482$ \\
\hline Systemic CVaR (\$) & $189,843,732$ & 463,476 & $6,433,389,853$ & $104,241,779$ & $7,136,955$ & $1,319,704,470$ \\
\hline
\end{tabular}


Table 8: Estimation results for banks' funding costs and loan growth - APRA data from 2008-2014.

Table 8 reports the estimation results for the effect of capital on funding costs in Panel A, and lending activity in Panel B. The main explanatory variable is banks' capital buffer. All explanatory variables are one-quarter lagged, except SIZE and GDP_GR. For Column (4), the additional controls are time to maturity (TTM) and the indicator variable for Moody's credit ratings (RATINGS). The loan growth measures are annualised, and adjusted for inflation as of December 2014. We do not include the variable IFRS as this analysis spans from 2008 onwards. PROFIT is also excluded as it has a higher correlation with CAP_BUFFER. All variables (except size) are winsorized at the $5^{\text {th }}$ and $95^{\text {th }}$ percentiles. $* / * * / * * *$ indicate significance at the $10 \%, 5 \%$ and $1 \%$ level, respectively.

\section{Panel A: Banks' funding costs}

\begin{tabular}{|c|c|c|c|c|}
\hline Dependent variable & $\begin{array}{l}\text { (1) Spread on refinanced } \\
\text { debt over } 3 \text { months }\end{array}$ & $\begin{array}{l}\text { (2) Spread on total } \\
\text { refinanced debt }\end{array}$ & $\begin{array}{l}\text { (3) Spread on } \\
\text { total debt }\end{array}$ & $\begin{array}{l}\text { (4) Mid spread } \\
\text { on bond }\end{array}$ \\
\hline \multirow[t]{2}{*}{ L1_CAP_BUFFER } & $-0.2519 * * *$ & $-0.1146 * * *$ & -0.0573 & $-0.4947 * * *$ \\
\hline & $(0.0447)$ & $(0.0285)$ & $(0.0383)$ & $(0.1810)$ \\
\hline \multirow[t]{2}{*}{ L1_LIQ } & $0.1011 * *$ & $0.0545^{*}$ & 0.0165 & $0.2793 * * *$ \\
\hline & $(0.0504)$ & $(0.0309)$ & $(0.0353)$ & $(0.0679)$ \\
\hline \multirow[t]{2}{*}{ L1_HLOAN } & 0.0288 & 0.0091 & 0.0124 & -0.0050 \\
\hline & $(0.0191)$ & $(0.0132)$ & $(0.0106)$ & $(0.0232)$ \\
\hline \multirow[t]{2}{*}{ L1_LOAN_GR } & -0.0054 & -0.0038 & $-0.0064 *$ & -0.0173 \\
\hline & $(0.0056)$ & $(0.0038)$ & $(0.0038)$ & $(0.0118)$ \\
\hline \multirow[t]{2}{*}{ L1_DEP } & $-0.0348 * * *$ & 0.0056 & -0.0057 & 0.0078 \\
\hline & $(0.0122)$ & $(0.0072)$ & $(0.0058)$ & $(0.0221)$ \\
\hline \multirow[t]{2}{*}{ SIZE } & -0.5245 & 0.0351 & $0.9851 * *$ & -0.2406 \\
\hline & $(0.3908)$ & $(0.2593)$ & $(0.4795)$ & $(0.2694)$ \\
\hline \multirow[t]{2}{*}{ GDP_GR } & -0.1110 & $-0.3202 * * *$ & $-0.5866^{* * *}$ & 0.1605 \\
\hline & $(0.0822)$ & $(0.0521)$ & $(0.0648)$ & $(0.1446)$ \\
\hline \multirow[t]{2}{*}{ TTM } & & & & $0.0471 * *$ \\
\hline & & & & $(0.0207)$ \\
\hline RATINGS & $\mathrm{N}$ & $\mathrm{N}$ & $\mathrm{N}$ & $\mathrm{Y}$ \\
\hline Bank fixed effects & Y & $\mathrm{Y}$ & $\mathrm{Y}$ & $\mathrm{N}$ \\
\hline Adj R-squared & 0.5862 & 0.4435 & 0.4736 & 0.4817 \\
\hline No. of obs & 509 & 514 & 589 & 150 \\
\hline
\end{tabular}




\begin{tabular}{|c|c|c|c|c|c|}
\hline \multicolumn{6}{|c|}{ Panel B: Lending activity } \\
\hline Dependent variable & $\begin{array}{l}\text { (1) Net interest } \\
\text { margin on loans }\end{array}$ & $\begin{array}{l}\text { (2) Spread on } \\
\text { loans }\end{array}$ & $\begin{array}{l}\text { (3) Total loan } \\
\text { growth }\end{array}$ & $\begin{array}{l}\text { (4) Commercial } \\
\text { loan growth }\end{array}$ & $\begin{array}{l}\text { (5) Housing loan } \\
\text { growth }\end{array}$ \\
\hline \multirow[t]{2}{*}{ L1_CAP_BUFFER } & $0.2379 * * *$ & $0.3291 * * *$ & $-0.6686^{*}$ & $-2.4527 * * *$ & $-1.3425 * * *$ \\
\hline & $(0.0290)$ & $(0.070)$ & $(0.3961)$ & $(0.6482)$ & $(0.5179)$ \\
\hline \multirow[t]{2}{*}{ L1_LIQ } & 0.0176 & 0.0938 & 0.2373 & -0.1097 & 0.2257 \\
\hline & $(0.0218)$ & $(0.0609)$ & $(0.3726)$ & $(0.580)$ & $(0.5746)$ \\
\hline \multirow[t]{2}{*}{ L1_HLOAN } & $-0.0382 * * *$ & $-0.0809 * * *$ & -0.1872 & $-1.0233 * * *$ & 0.1238 \\
\hline & $(0.0084)$ & $(0.0216)$ & $(0.1450)$ & $(0.1966)$ & $(0.1659)$ \\
\hline \multirow[t]{2}{*}{ L1_LOAN_GR } & -0.0057 & $-0.0392 * * *$ & & & \\
\hline & $(0.0036)$ & $(0.0094)$ & & & \\
\hline \multirow[t]{2}{*}{ L1_DEP } & $0.0105 * *$ & 0.0013 & $0.1616^{* *}$ & $0.3172 * * *$ & 0.0758 \\
\hline & $(0.0046)$ & $(0.0102)$ & $(0.0728)$ & $(0.1063)$ & $(0.1049)$ \\
\hline \multirow[t]{2}{*}{ SIZE } & $-0.850 * * *$ & $-0.9517 * *$ & $-8.0695 * *$ & $17.4194 * * *$ & $-15.1833 * * *$ \\
\hline & $(0.2104)$ & $(0.4677)$ & $(3.8031)$ & $(3.5373)$ & $(5.2957)$ \\
\hline \multirow[t]{2}{*}{ GDP_GR } & 0.0281 & $-0.6909 * * *$ & $-2.7436 * * *$ & -0.0982 & $-3.0329 * * *$ \\
\hline & $(0.0329)$ & $(0.1019)$ & $(0.5705)$ & $(0.9734)$ & $(0.8309)$ \\
\hline Bank fixed effects & $\mathrm{Y}$ & $\mathrm{Y}$ & $\mathrm{Y}$ & $\mathrm{Y}$ & $\mathrm{Y}$ \\
\hline Adj R-squared & 0.858 & 0.8515 & 0.4276 & 0.3377 & 0.3139 \\
\hline No. of obs & 589 & 589 & 589 & 587 & 551 \\
\hline
\end{tabular}

